Article

\title{
Four Mixed-Ligand Zn(II) Three-Dimensional Metal-Organic Frameworks: Synthesis, Structural Diversity, and Photoluminescent Property
}

\author{
Chih-Chieh Wang ${ }^{1, *}$, Szu-Yu Ke ${ }^{1}$, Chia-Wen Cheng ${ }^{1}$, Yu-Wen Wang ${ }^{1}$, Hsiao-Shan Chiu ${ }^{1}$, \\ Yu-Chien Ko ${ }^{1}$, Ning-Kuei Sun ${ }^{1}$, Mei-Lin Ho ${ }^{1, *}$, Chung-Kai Chang ${ }^{2}$, Yu-Chun Chuang ${ }^{2}$ and \\ Gene-Hsiang Lee ${ }^{3}$ \\ 1 Department of Chemistry, Soochow University, Taipei 11102, Taiwan; sarah6017@yahoo.com.tw (S.-Y.K.); \\ wendythu07@gmail.com (C.-W.C.); 01133046@scu.edu.tw (Y.-W.W.); anhhhh@hotmail.com (H.-S.C.); \\ perfectshow15@gmail.com (Y.-C.K.); coco830824@gmail.com (N.-K.S.) \\ 2 National Synchrotron Radiation Research Center, Hsinchu 30076, Taiwan; haha5ckai@gmail.com (C.-K.C.); \\ chuang.yc@nsrrc.org.tw (Y.-C.C.) \\ 3 Instrumentation Center, National Taiwan University, Taipei 10617, Taiwan; ghlee@ntu.edu.tw \\ * Correspondence: ccwang@scu.edu.tw (C.-C.W.); meilin_ho@scu.edu.tw (M.-L.H.); \\ Tel.: +886-2-2881-9471 (ext. 6828) (C.-C.W.)
}

Received: 29 October 2017; Accepted: 21 November 2017; Published: 25 November 2017

\begin{abstract}
Assemblies of four three-dimensional (3D) mixed-ligand coordination polymers (CPs) having formulas, $\left\{\left[\mathrm{Zn}_{2}(\mathrm{bdc})_{2}(4-\mathrm{bpdh})\right] \cdot \mathrm{C}_{2} \mathrm{H}_{5} \mathrm{OH} \cdot 2 \mathrm{H}_{2} \mathrm{O}\right\}_{\mathrm{n}} \quad(\mathbf{1}), \quad[\mathrm{Zn}(\mathrm{bdc})(4-\mathrm{bpdh})]_{\mathrm{n}}$ (2), $\left\{\left[\mathrm{Zn}_{2}(\mathrm{bdc})_{2}(4-\mathrm{bpdh})_{2}\right] \cdot(4-\mathrm{bpdh})\right\}_{\mathrm{n}}(3)$, and $\left\{[\mathrm{Zn}(\mathrm{bdc})(4-\mathrm{bpdh})] \cdot \mathrm{C}_{2} \mathrm{H}_{5} \mathrm{OH}\right\}_{\mathrm{n}}(4)\left(\mathrm{bdc}^{2-}=\right.$ dianion of 1,4-benzenedicarboxylic acid, 4-bpdh = 2,5-bis(4-pyridyl)-3,4-diaza-2,4-hexadiene) have been synthesized and structurally characterized by single-crystal X-ray diffraction method. Structural determination reveals that the coordination numbers (geometry) of $\mathrm{Zn}$ (II) ions in 1, 2, 3 , and 4 are five (distorted square-pyramidal (SP)), six (distorted octahedral $\left(\mathrm{O}_{h}\right)$ ), five (trigonal-bipyramidal (TBP)), and four (tetrahedral $\left(\mathrm{T}_{d}\right)$ ), respectively, and are bridged by 4-bpdh with bis-monodentate coordination mode and $\mathrm{bdc}^{2-}$ ligands with bis-bidentate in $\mathbf{1}$, chelating/bidentate in 2, bis-monodentate and bis-bidentate in 3, and bis-monodentate in 4 , to generate two-fold interpenetrating 3D cube-like metal-organic framework (MOF) with pcu topology, non-interpenetrating 3D MOF, two-fold interpenetrating 3D rectangular-box-like MOF with pcu topology and five-fold interpenetrating diamondoid-like MOF with dia topology, respectively. These different intriguing architectures indicate that the coordination numbers and geometries of $\mathrm{Zn}$ (II) ions, coordination modes of $\mathrm{bdc}^{2-}$ ligand, and guest molecules play important roles in the construction of MOFs and the formation of the structural topologies and interpenetrations. Thermal stabilities, and photoluminescence study of 1-4 were also studied in detail. The complexes exhibit ligands based photoluminescence properties at room temperature.
\end{abstract}

Keywords: coordination polymer; metal-organic framework; structural topology; interpenetration; photoluminescence

\section{Introduction}

Coordination polymers (CPs) [1,2], or metal-organic frameworks (MOFs) [1,2], containing guest molecules are very attractive research fields owing to their designable structure, unusual flexibilities, and tunable functional application [3-8], which provide a unique opportunity for developing advanced functional materials for studying fundamental nanomolecular assemblies in confined spaces $[9,10]$. In the past decade, the design and preparation of coordination polymers with MOFs or well-regulated 
networks have attracted great interest for the sake of the potential applications in catalysis, gas adsorption, nonlinear optics, conductivity, luminescence, and magnetism [11-18]. In principle, the assembly of CPs can be influenced by several factors, such as the reaction condition, nature of anions, coordination geometry of the metal ions, flexibility and coordination modes of the ligands, temperature, solvent, and so on $[19,20]$. Among these factors, the coordination geometry of the central metal ions and flexibility and coordination modes of the ligands have been well demonstrated that they can control the structural topology, pore size, and interpenetration of MOFs, resulting in the structural diversity and related properties [13-15,21-23]. Based on this concept, utilizing suitable organic spacers with functional groups that are capable of bridging metal centers to construct the well-defined crystalline materials has shown to be a fast developing research in connection with crystal engineering, coordination chemistry, supramolecular chemistry, and material science [24-28]. A framework with long spacer ligands can be interwoven by the incorporation of other nets, resulting in the formation of interpenetrating architectures [29-33]. The degree of interpenetration relies on factors that include temperature [34], concentration, templates [35], ligand type [36], and guest removal/inclusion [37-40]. For this purpose, constructing a series of three-dimensional (3D) MOFs with different structural topology under the same synthetic condition and discussing the variable factors, including the coordination geometry, and coordination modes, and structural conformation of ligands, has become an interesting issue. Recently, diaza-base ligands, such as 1,4-bis(4-pyridyl)-2,3-diaza-1,3-butadiene (4-bpd), 2,5-bis(4-pyridyl)-3,4-diaza-2,4-hexadiene (4-bpdh), 1,4-bis(3-pyridyl)-2,3-diaza-1,3-butadiene (3-bpd), and 2,5-bis(3-pyridyl)-3,4-diaza-2,4-hexadiene (3-bpdh) with the zigzag conformation of the spacer diaza moiety ( $-\mathrm{CR}=\mathrm{N}-\mathrm{N}=\mathrm{CR}-$ ) between the two pyridyl groups have been justified to play important roles in the design of the multi-dimensional MOFs [41-72]. Many three-dimensional (3D) structural topologies have been constructed either by using various metal centers bridged by one of the diaza-base ligands that is associated with one multi-carboxylate ligands, or by using one metal center bridged by one of the diaza-base ligand associated with various multi-carboxylate ligands [52-72]. However, the structural diversity of 3D CPs constructed based only on one metal center bridged by the same diaza-base ligand and dicarboxylate ligands under the same synthetic condition is rare and worth systematic study. Focusing on this approach, we report here four 3D Zn(II)-bpdh-bdc CPs, $\left\{\left[\mathrm{Zn}_{2}(\mathrm{bdc})_{2}(4-\mathrm{bpdh})\right] \cdot \mathrm{C}_{2} \mathrm{H}_{5} \mathrm{OH} \cdot 2 \mathrm{H}_{2} \mathrm{O}\right\}_{\mathrm{n}}(\mathbf{1})$, [Zn(bdc)(4-bpdh) $]_{\mathrm{n}}$ (2), $\left\{\left[\mathrm{Zn}_{2}(\mathrm{bdc})_{2}(4-\mathrm{bpdh})_{2}\right] \cdot(4-\mathrm{bpdh})\right\}_{\mathrm{n}}(3)$, and $\left\{[\mathrm{Zn}(\mathrm{bdc})(4-\mathrm{bpdh})] \cdot \mathrm{C}_{2} \mathrm{H}_{5} \mathrm{OH}\right\}_{\mathrm{n}}$ (4) (where 4-bpdh = 2,5-bis(4-pyridyl)-3,4-diaza-2,4-hexadiene) and bdc $^{2-}=$ dianion of 1,4-benzenedicarboxylic acid), in which the $\mathrm{Zn}$ (II) centres adopts four different kinds of coordination geometries bridged by the 4-bpdh with a bis-monodentate coordination modes and $\mathrm{bdc}^{2-}$ ligands with three kinds of coordination modes, including bis-bidentate, chelating/bidentate, and bis-monodentate, to construct their 3D MOFs with different structural topology and network interpenetration.

\section{Materials and Methods}

\subsection{Materials and Physical Techniques}

General: 4-bpdh was synthesized according to the literature procedure [41]. All of the chemicals were of reagent grade and were used as commercially obtained without further purification. Elementary analyses (carbon, hydrogen and nitrogen) were performed using a Perkin-Elmer 2400 elemental analyzer (PerkinElmer, Taipei, Taiwan). IR spectra were recorded on a Nicolet Fourier Transform IR MAGNA-IR 500 spectrometer (Thermo Fisher Scientific, Waltham, MA, USA) in the range of $500-4000 \mathrm{~cm}^{-1}$ using the $\mathrm{KBr}$ disc technique. Thermogravimetric analysis (TGA) of compounds 1-4 was performed on a computer-controlled Perkin-Elmer 7 Series/UNIX TGA7 analyzer (PerkinElmer, Taipei, Taiwan). Single-phased powder samples were loaded into alumina pans and heated with a ramp rate of $5{ }^{\circ} \mathrm{C} / \mathrm{min}$ from room temperature to $700{ }^{\circ} \mathrm{C}$ under a nitrogen atmosphere. The adsorption isotherm of $\mathrm{N}_{2}, \mathrm{H}_{2}(77 \mathrm{~K})$, and $\mathrm{CO}_{2}(195 \mathrm{~K})$ for $\mathbf{1 - 4}$ was measured in the gaseous state by using BELSORP-max volumetric adsorption equipment from BEL, Osaka, Japan. In the sample 
cell $\left(\sim 1.8 \mathrm{~cm}^{3}\right)$, maintained at $\mathrm{T} \pm 0.03 \mathrm{~K}$, was placed the adsorbent sample $(\sim 100-150 \mathrm{mg})$, which has been prepared at $180^{\circ} \mathrm{C}$ for $\mathbf{1 - 4}$ and $10^{-2} \mathrm{~Pa}$ for about $24 \mathrm{~h}$ prior to measurement of the isotherm. The adsorbate was placed into the sample cell, and then the change of pressure was monitored and the degree of adsorption was determined by the decrease of pressure at equilibrium state. All of the operations were through automatically computer-controlled.

\subsection{Synthesis of $\left\{\left[Z n_{2}(b d c)_{2}(4-b p d h)\right] \cdot \mathrm{C}_{2} \mathrm{H}_{5} \mathrm{OH} \cdot 2 \mathrm{H}_{2} \mathrm{O}\right\}_{n}(\mathbf{1})$ and $[\mathrm{Zn}(b d c)(4-b p d h)]_{n}$ (2)}

An ethanol $/ \mathrm{H}_{2} \mathrm{O}$ solution $(1: 1,4 \mathrm{~mL})$ of terephthalic disodium salt $\left(\mathrm{Na}_{2} \mathrm{bdc} 0.025 \mathrm{mmol}\right)$ was added to an ethanol/water $(1: 1,8 \mathrm{~mL})$ solution of $\mathrm{ZnCl}_{2}(0.025 \mathrm{mmol})$ and 2,5-bis(4-pyridyl)-3, 4-diaza-2,4-hexadiene $(0.050 \mathrm{mmol})$ at room temperature. After standing for one week, light-yellow block crystals of 1 (yield, $35.3 \%$ based on terephthalic disodium salt) and light-yellow plate crystals of 2 (yield, $24.9 \%$ based on terephthalic disodium salt) were obtained, which are suitable for X-ray diffraction analysis. The resulting crystals of $\mathbf{1}$ and $\mathbf{2}$ were collected by filtration, washed several times with distilled water, and dried in air. Anal. Calc. for de-solvated (1), $\mathrm{C}_{30} \mathrm{H}_{14} \mathrm{~N}_{4} \mathrm{O}_{8} \mathrm{Zn}_{2}$ : C 52.28, N 8.13, H 2.04. Found: C 51.85, N 8.01, H 2.54. IR (KBr pellet): $v=3400$ (m), 1638 (s), 1616 (vs), 1504 (m), $1426(\mathrm{~m}), 1390(\mathrm{~s}), 1298(\mathrm{~m}), 1064(\mathrm{w}), 1029(\mathrm{w}), 1016(\mathrm{w}), 887(\mathrm{w}), 825(\mathrm{~m}), 749(\mathrm{~s}) \mathrm{cm}^{-1}$. Anal. Calc. for $\mathrm{C}_{22} \mathrm{H}_{18} \mathrm{~N}_{4} \mathrm{O}_{4} \mathrm{Zn}_{1}$ (2): C 56.49, N 11.98, H 3.88; Found: C 56.29, N 11.86, H 3.84. IR (KBr pellet): $v=1608$ (s), 1572 (vs), 1503 (s), 1390 (vs), 1331 (m), 1303 (m), 1223 (m), 1066 (m), 1016 (m), 835 (s), $754(\mathrm{~s}) \mathrm{cm}^{-1}$.

\subsection{Synthesis of $[\mathrm{Zn}(b d c)(4-b p d h)]_{n}(\mathbf{2}),\left\{\left[Z n_{2}(b d c)_{2}(4-b p d h)_{2}\right] \cdot(4-b p d h)\right\}_{n}(3)$ and $\left\{[\mathrm{Zn}(b d c)(4-b p d h)] \cdot \mathrm{C}_{2} \mathrm{H}_{5} \mathrm{OH}\right\}_{n}(4)$}

An ethanol $/ \mathrm{H}_{2} \mathrm{O}(1: 3)$ solution $(4 \mathrm{~mL})$ of terephthalic disodium salt $\left(\mathrm{Na}_{2} \mathrm{bdc} 0.025 \mathrm{mmol}\right)$ was added to an ethanol/water (1:3) solution $(8 \mathrm{~mL})$ of $\mathrm{ZnCl}_{2}(0.025 \mathrm{mmol})$ and 2,5-bis(4-pyridyl)-3, 4-diaza-2,4-hexadiene (4-bpdh) $(0.05 \mathrm{mmol})$ at room temperature. After standing for one week, the light-yellow plate crystals of 2 (yield, $22.8 \%$ based on terephthalic disodium salt), yellow block crystals of 3 (yield, 12.2\% based on terephthalic disodium salt), and orange-yellow block crystals of 4 (yield, $30.2 \%$ based on terephthalic disodium salt), respectively, were obtained, which are suitable for X-ray diffraction analysis. The resulting crystals of $\mathbf{2} \mathbf{4}$ were collected by filtration, washed several times with distilled water, and dried in air. Anal. Calc. for $\mathrm{C}_{22} \mathrm{H}_{18} \mathrm{~N}_{4} \mathrm{O}_{4} \mathrm{Zn}_{1}$ (2): C 56.49, N 11.98, H 3.88; Found: C 56.29, N 11.86, H 3.84. IR (KBr pellet): $v$ = 1608 (s), 1572 (vs), 1503 (s), 1390 (vs), 1331 (m), 1303 (m), $1223(\mathrm{~m}), 1066(\mathrm{~m}), 1016(\mathrm{~m}), 835$ (s), 754 (s) cm ${ }^{-1}$. Anal. Calc. for desolvated (3), $\mathrm{C}_{44} \mathrm{H}_{36} \mathrm{~N}_{8} \mathrm{O}_{8} \mathrm{Zn}_{2}: \mathrm{C}$ 56.49, N 11.98, H 3.88; Found: C 56.27, N 12.08, H 4.15. IR (KBr pellet): $v=1615$ (vs), 1570 (s), 1500 (m), 1397 (s), 1367 (s), $1292(\mathrm{~m}), 1220(\mathrm{~m}), 1091(\mathrm{~m}), 1065(\mathrm{w}), 1019(\mathrm{w}), 830(\mathrm{~m}), 753(\mathrm{~m}) \mathrm{cm}^{-1}$. Anal. Calc. for $\mathrm{C}_{24} \mathrm{H}_{24} \mathrm{~N}_{4} \mathrm{O}_{5} \mathrm{Zn}_{1}$ (4): C 56.10, N 10.91, H 4.71; Found: C 56.68, N 11.18, H 4.62. IR (KBr pellet): $v=3384(\mathrm{~m}), 1616(\mathrm{vs}), 1568(\mathrm{~s}), 1500(\mathrm{~m}), 1403(\mathrm{~s}), 1344(\mathrm{~s}), 1292(\mathrm{~m}), 1220(\mathrm{~m}), 1140(\mathrm{~m}), 1089(\mathrm{w})$, $1064(\mathrm{~m}), 1027(\mathrm{~m}), 884(\mathrm{w}), 830(\mathrm{~m}), 745(\mathrm{~m})$.

\subsection{Crystallographic Data Collection and Refinements}

Single-crystal structure analysis for compounds 1-4 was performed out on a Siemens SMART diffractomer with a charge coupled detector (CCD) detector with Mo radiation $(\lambda=0.71073 \AA)$ at $100 \mathrm{~K}$. A preliminary orientation matrix and unit cell parameters were determined from 3 runs of 15 frames each, each frame correspond to a $0.3^{\circ}$ scan in $10 \mathrm{~s}$, following by spot integration and least-squares refinement. For each structure, data were measured using $\omega$ scans of $0.3^{\circ}$ per frame for $20 \mathrm{~s}$ until a complete hemisphere had been collected. Cell parameters were retrieved using SMART [73] software and refined with SAINT [74] on all of the observed reflections. Data reduction was performed with the SAINT [75] software and corrected for Lorentz and polarization effects. Absorption corrections were applied with the program SADABS [75]. Direct phase determination and subsequent difference Fourier map synthesis yielded the positions of all the atoms, which were subjected to anisotropic refinements for non-hydrogen atoms and isotropic for hydrogen atoms. The 
final full-matrix, least-squares refinement on $F^{2}$ was applied for all of the observed reflections $(\mathrm{I}>2 \sigma(\mathrm{I}))$. All of the calculations were performed by using the SHELXTL-PC V 5.03 software package [76]. Crystal data and details of the data collection and structure refinements for 1-4 are summarized in Table 1. CCDC-1478481, 1478482, 1478483 and 1478484 for 1, 2, 4, and 3, respectively, contains the supplementary crystallographic data for this paper. These data can be obtained free of charge at www. ccdc.cam.ac.uk/conts/retrieving.html or from the Cambridge Crystallographic Data Centre, 12, Union Road, Cambridge CB2 1EZ, UK; fax: (internat.)+44-1223/336-033; email: deposit@ccdc.cam.ac.uk.

Table 1. Crystal data and refinement details of compounds 1-4.

\begin{tabular}{|c|c|c|c|c|}
\hline Compound & 1 & 2 & 3 & 4 \\
\hline $\begin{array}{c}\text { empirical formula } \\
\text { formula mass }\left(\mathrm{g} \mathrm{mol}^{-1}\right)\end{array}$ & $\begin{array}{c}\mathrm{C}_{32} \mathrm{H}_{22} \mathrm{~N}_{4} \mathrm{O}_{11} \mathrm{Zn}_{2} \\
769.28\end{array}$ & $\begin{array}{c}\mathrm{C}_{22} \mathrm{H}_{18} \mathrm{~N}_{4} \mathrm{O}_{4} \mathrm{Zn}_{1} \\
467.77\end{array}$ & $\begin{array}{c}\mathrm{C}_{51} \mathrm{H}_{43.5} \mathrm{~N}_{10} \mathrm{O}_{8} \mathrm{Zn}_{2} \\
1055.20\end{array}$ & $\begin{array}{c}\mathrm{C}_{26} \mathrm{H}_{30} \mathrm{~N}_{4} \mathrm{O}_{6} \mathrm{Zn}_{1} \\
559.91\end{array}$ \\
\hline crystal system & Triclinic & Monoclinic & Triclinic & Monoclinic \\
\hline space group & $P-1$ & $P 2_{1} / c$ & $P-1$ & $\mathrm{C} 2 / \mathrm{c}$ \\
\hline$a(\AA)$ & $10.893(2)$ & $7.4958(5)$ & $10.4787(5)$ & $27.020(2)$ \\
\hline$b(\AA)$ & $10.899(2)$ & $13.5492(9)$ & $14.7264(7)$ & $6.0013(4)$ \\
\hline$c(\AA)$ & $18.088(3)$ & $19.512(1)$ & $15.6046(7)$ & $20.136(1)$ \\
\hline$\alpha(\mathrm{deg})$ & $83.619(3)$ & 90.00 & $98.494(1)$ & 90.00 \\
\hline$\beta(\mathrm{deg})$ & $81.716(3)$ & $90.927(2)$ & $92.658(1)$ & $128.095(1)$ \\
\hline$\gamma(\mathrm{deg})$ & $88.729(3)$ & 90.00 & $104.9995(9)$ & 90.00 \\
\hline$V\left(\AA^{3}\right)$ & $2112.0(5)$ & 1981.4(2) & $2291.4(2)$ & $2569.7(3)$ \\
\hline Z & 2 & 4 & 2 & 4 \\
\hline $\mathrm{T}(\mathrm{K})$ & $150(2)$ & $150(2)$ & $200(2)$ & $150(2)$ \\
\hline$D_{\text {calcd }}\left(\mathrm{g} \mathrm{cm}^{-3}\right)$ & 1.210 & 1.568 & 1.529 & 1.447 \\
\hline$\mu\left(\mathrm{mm}^{-1}\right)$ & 1.187 & 1.278 & 1.116 & 1.004 \\
\hline$\theta$ range $(\mathrm{deg})$ & $1.88-25.0$ & $1.83-27.5$ & $1.32-27.5$ & $1.92-27.5$ \\
\hline total no. of data collected & 22,177 & 18,016 & 29,841 & 9404 \\
\hline no. of unique data & 7422 & 4561 & 10,488 & 2939 \\
\hline no. of obsd data $(\mathrm{I}>2 \sigma(\mathrm{I}))$ & 5511 & 3594 & 8875 & 2588 \\
\hline$R_{\text {int }}$ & 0.0884 & 0.0588 & 0.0398 & 0.0355 \\
\hline refine params & 456 & 282 & 612 & 181 \\
\hline$R_{1}, w R_{2}^{1}(\mathrm{I}>2 \sigma(\mathrm{I}))$ & $0.1073,0.2718$ & $0.0446,0.1025$ & $0.0477,0.1307$ & $0.0588,0.1620$ \\
\hline$R_{1}, w R_{2}{ }^{1}$ (all data) & $0.1367,0.2881$ & $0.0621,0.1103$ & $0.0577,0.1414$ & $0.0653,0.1684$ \\
\hline $\mathrm{GOF}^{2}$ & 1.153 & 1.018 & 1.070 & 1.053 \\
\hline
\end{tabular}

\subsection{In Situ X-ray Powder Diffraction}

The powder X-ray diffraction patterns of compounds 1-4 was measured at the BL01C2 beamline of National Synchrotron Radiation Research Center (NSRRC) in city, Taiwan. The wavelength of the incident X-rays was $1.0332 \AA$ (12.0 KeV), delivered from the superconducting wavelength-shifting magnet and a $\mathrm{Si}(111)$ double-crystal monochromator. The diffraction pattern was recorded with a Mar345 imaging-plate detector and typical exposure duration of $2 \mathrm{~min}$. The one-dimensional powder diffraction profile was converted with GSAS-II program [77]. The diffraction angles were calibrated according to Bragg positions of lanthanum boride (SRM660b) standards.

\subsection{Spectral Measurement}

Compounds 1-4 were obtained with a HITACHI U-3900Hspectrophotometer (Hitachi High Technologies America, Inc., Schaumburg, IL, USA) equipped with an integrating sphere accessory $\left(\mathrm{Al}_{2} \mathrm{O}_{3}\right.$ was used as a reference). In order to investigate the possible differences in photoluminescence of 1-4 due to the variation of in topology, 1-4 were measured with a confocal mode of a Mono-Vista confocal Raman microscope system (Princeton Instruments, Acton, MA, USA). In this approach, a $325 \mathrm{~nm}$ laser line was used as an excitation source throughout the measurements. The photoluminescence was separated from the scattering light of excitation pulse by an edge filter with a cut-off wavelength of $325 \mathrm{~nm}$. Subsequently, the luminescence was collected by an optical assembly to the entrance slit of a polychromator (blazed at $500 \mathrm{~nm}$ ), which was coupled with a sensitive charge 
coupled detector (CCD, Princeton Instruments, PI-MAX). The CCD was operated in shutter mode, and the measurements were performed with $100 \mathrm{~ms}$ exposure time.

\section{Results and Discussion}

\subsection{Syntheses and Characterization of Compounds 1-4}

Four CPs 1-4 with different 3D MOFs were synthesized on the basis of the selection of reaction solvent systems, while the other synthetic parameters were intentionally held constant. The dimensionality and topology of the networks that were produced in this work are determined by the coordination environments of $\mathrm{Zn}(\mathrm{II})$ and bridging modes of $\mathrm{bdc}^{2-}$ and 4-bpdh ligands, which are clearly dictated by the solvent molecules. The reaction in $\mathrm{EtOH} / \mathrm{H}_{2} \mathrm{O}(12 \mathrm{~mL}, v / v$ 1:1) solvent results in the formation of $\mathbf{1}$ and $\mathbf{2}$, while $\mathbf{2}-\mathbf{4}$ are formed in $\mathrm{EtOH} / \mathrm{H}_{2} \mathrm{O}(12 \mathrm{~mL}, v / v$ 1:3) solvent (Scheme 1). The experiments reveal that the $\mathrm{EtOH} / \mathrm{H}_{2} \mathrm{O}$ ratios are critical to form supramolecular isomers 1-4. In order to explore the role of $\mathrm{EtOH} / \mathrm{H}_{2} \mathrm{O}$ ratios on the assembled system of $\mathrm{Zn}(\mathrm{II}) / \mathrm{bdc}^{2-} / 4$-bpdh, we carried out a series of related experiments by changing the volumetric ratio of $\mathrm{EtOH} / \mathrm{H}_{2} \mathrm{O}(12 \mathrm{~mL})$ from 5:1 to 1:5. The volumetric ratio of EtOH/ $\mathrm{H}_{2} \mathrm{O}$ used in the synthetic processes and the related yields of 1-4 are recorded in a tabular form (Table S1 deposited in the Supplementary Information). However, the formations of the CPs 1-4 show specificities to the volumetric ratios of 1:1 and 1:2, respectively, at least for the current experimental results. It clearly shows that the solvent ratios have effects on the final products and the simple change of mixed solvent ratio can generate quite different structures of the resultant CPs. All of the products were confirmed through powder XRD measurement of the as-synthesized samples (Figures S1b-S4b deposited in the Supplementary Information). The powder X-ray diffraction (PXRD) patterns of these compounds are in a good agreement with the simulated ones calculated from the corresponding single-crystal X-ray diffraction data. The most relevant IR features for 1-4 are those that are associated with the $\mathrm{bdc}^{2-}$ ligands and almost identical throughout the region from 500 to $4000 \mathrm{~cm}^{-1}$, showing strong characteristic absorption bands in $1300-1600 \mathrm{~cm}^{-1}$ range, attributed to the carboxylate groups of $\mathrm{bdc}^{2-}$ ligands.

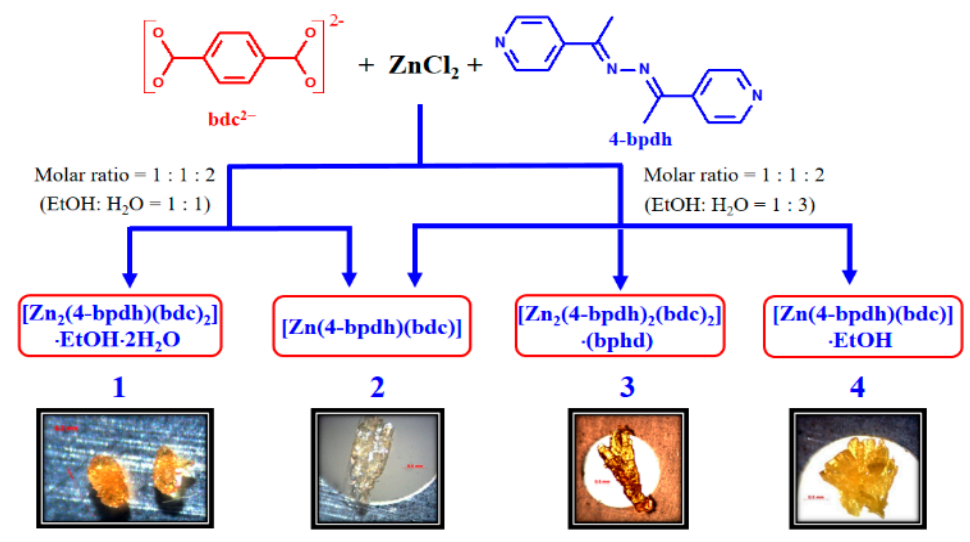

Scheme 1. Synthetic representation of compounds 1-4.

\subsection{Structural Description of $\left\{\left[\mathrm{Zn}_{2}(b d c)_{2}(4-b p d h)\right] \cdot \mathrm{C}_{2} \mathrm{H}_{5} \mathrm{OH} \cdot 2 \mathrm{H}_{2} \mathrm{O}\right\}_{n}(\mathbf{1})$}

Compound 1 crystallizes in the triclinic $P-1$ space group, in which the asymmetric unit contains two $\mathrm{Zn}$ (II) metal center, two bdc ${ }^{2-}$, one 4-bpdh ligands and one ethanol, two water guest molecules. The molecular structure of $\mathbf{1}$ shown in Figure 1a reveals that two crystallographically independent $\mathrm{Zn}(\mathrm{II})$ ions $(\mathrm{Zn}(1)$ and $\mathrm{Zn}(2))$ are both five coordinate bonded with four oxygen atoms of four $\mathrm{bdc}^{2-}$ ligands in the equatorial plane with $\mathrm{Zn}-\mathrm{O}$ distances in the range of 2.010(7)-2.050(7) $\AA$ and one nitrogen atom of one 4-bpdh ligands at the axial position with $\mathrm{Zn}-\mathrm{N}$ distances of 2.012(8) and 2.031(8) $\AA$, forming a distorted square-pyramidal (SP) geometry. The selected bond lengths 
and angles around the $\mathrm{Zn}(\mathrm{II})$ centres are listed in Table S2 (deposited in the Supplementary Information). In 1, four $\mathrm{bdc}^{2-}$ ligands adopting bis-bidentate coordination modes (Scheme 2a) connect two $\mathrm{Zn}$ (II) centres generating a paddle-wheel dinuclear $\left[\mathrm{Zn}_{2}\left(\mathrm{CO}_{2}\right)_{4}\right]$ secondary building unit (SBU), and each dinuclear SBU unit bridged by bdc ${ }^{2-}$ ligands to form two-dimensional (2D) planar layered frameworks with $(4,4)$ topology along the crystallographic $a b$ plane (Figure $1 \mathrm{~b}$ ). Adjacent layers are further pillared by 4-bpdh ligands with bis-monodentate coordination mode to complete its 3D cube-like open MOF (Figure 1c). Topological analysis by TOPOS [78] suggests the presence of a dinuclear $\left[\mathrm{Zn}_{2}\left(\mathrm{CO}_{2}\right)_{4}\right]$ unit, which act as a 6-connecting node, and the overall structure has a cubic (pcu) net topology. In each dinuclear SBU unit, two $\mathrm{Zn}$ (II) centres are

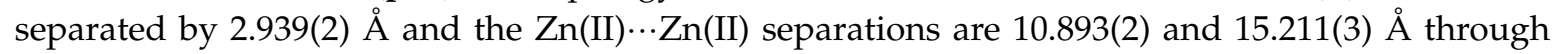
$\mathrm{bdc}^{2-}$ and 4-bpdh bridges, respectively. The intra-framework spaces are then occupied by the other crystallographically identical but independent networks, which interpenetrate the first one to form a two-fold interpenetrating 3D supramolecular architecture (as shown in Figure 1d) with the vacant pores intercalated with the ethanol and water molecules. The solvent-accessible volume is $23.7 \%$ (calculated with PLATON [79]) after the removal of guest solvent molecules. It is noteworthy that similar 3D MOF was constructed by $\mathrm{Zn}$ (II) ion with the same ligands, but display a three-fold interpenetrated coordination network found in the $\left\{\left[\mathrm{Zn}(\mathrm{Meazpy})_{0.5} \text { (terep) }\right]\right\}_{n}$ without any guest solvent molecules (Meazpy = N,N'-bis-(1pyridin-4-ylethylidene), terep = terephthalate) [63].

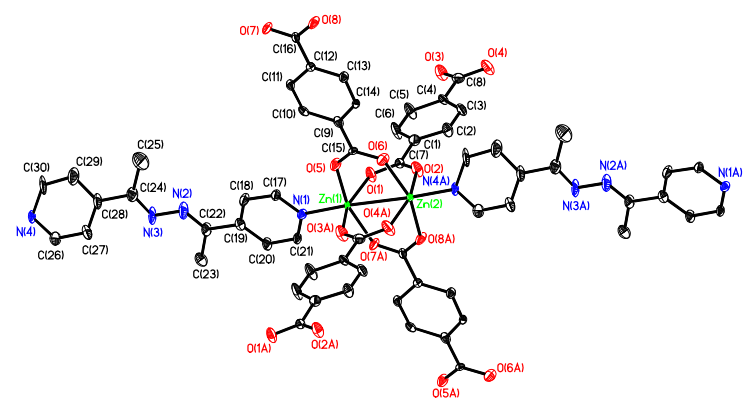

(a)

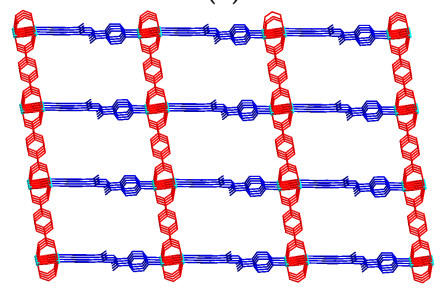

(c)

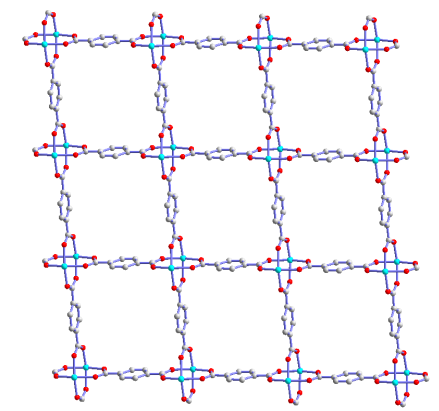

(b)

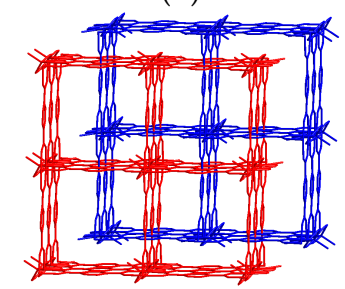

(d)

Figure 1. (a) Square-pyramidal coordination environments about $\mathrm{Zn}$ (II) ion in $\mathbf{1}$ with atom labelling scheme (Oak Ridge Thermal Ellipsoid Plot (ORTEP) drawing, 30\% thermal ellipsoids). The solvent molecules and $\mathrm{H}$ atoms are omitted for clarity; (b) The two-dimensional (2D) layered framework constructed by $\mathrm{Zn}(\mathrm{II})$ and bdc $^{2-}$ ligands with bis-bidentate coordination mode; (c) The three-dimensional (3D) cube-like metal-organic frameworks (MOF); (d) The two-fold interpenetrating 3D supramolecular architecture of $\mathbf{1}$.<smiles>[M]OC(O[M])c1ccc(C(O[M])O[M])cc1</smiles>

(a)

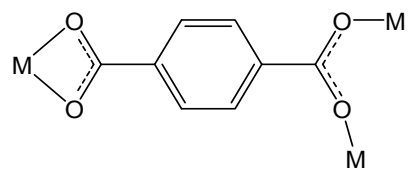

(b)

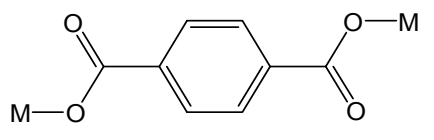

(c)

Scheme 2. Coordination modes of (a) bis-bidentate, (b) chelating/bidentate, and (c) bis-monodentate of bdc ${ }^{2-}$ ligand used in compounds $\mathbf{1 - 4}$. 


\subsection{Structural Description of $[\mathrm{Zn}(b d c)(4-b p d h)]_{n}(\mathbf{2})$}

Compound 2 crystallizes in the monoclinic $P 21 /$ c space group, in which the asymmetric unit contains one $\mathrm{Zn}(\mathrm{II})$ metal center, one $\mathrm{bdc}^{2-}$, and one 4-bpdh ligands. The ORTEP drawing view with atom numbering scheme of the $\mathrm{Zn}$ (II) coordination geometry is shown in Figure 2a, in which the $\mathrm{Zn}$ (II) ion is six-coordinate bonded to four oxygen atoms from three $\mathrm{bdc}^{2-}$ ligands with $\mathrm{Zn}-\mathrm{O}$ distances in the range of 2.045(2)-2.354(3) $\AA$ and two nitrogen atoms from two 4-bpdh ligands with $\mathrm{Zn}-\mathrm{N}$ distances of 2.155(2) and 2.226(2) $\AA$ to form a distorted octahedral $\left(\mathrm{O}_{h}\right)$ geometry. The selected bond lengths and angles around the $\mathrm{Zn}(\mathrm{II})$ centres are listed in Table S3 (deposited in the Supplementary Information). In 2 , four $b_{d c}{ }^{2-}$ ligands adopting chelating/bidentate coordination mode (Scheme $2 b$ ) connect two $\mathrm{Zn}$ (II) centres, generating a $\left[\mathrm{Zn}_{2}\left(\mathrm{CO}_{2}\right)_{4}\right]$ unit, and each dinuclear unit is bridged by bdc ${ }^{2-}$ ligand to form 2D sinusoidal-like layered frameworks (Figure 2 b) with $(4,4)$ topology along the crystallographic $b c$ plane. Adjacent layers are further interlinked via the connectivity between the dinuclear $\mathrm{Zn}$ (II) units and 4-bpdh ligands with bis-monodentate coordination mode in an alternate cross-linkage manner (Figure 2c) to complete its 3D MOF (Figure 2c,d). Such linkage manner of 4-bpdh ligands shown in 2 prevents the interpenetration of the unique 3D MOF. In each dinuclear unit, two $\mathrm{Zn}$ (II) centres are

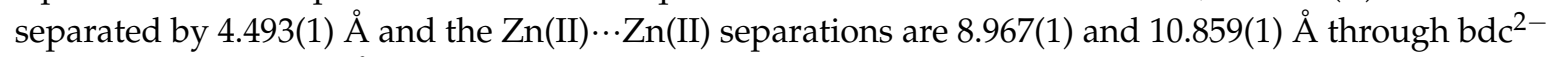
bridges and 13.549(1) $\AA$ through 4-bpdh bridge, respectively.

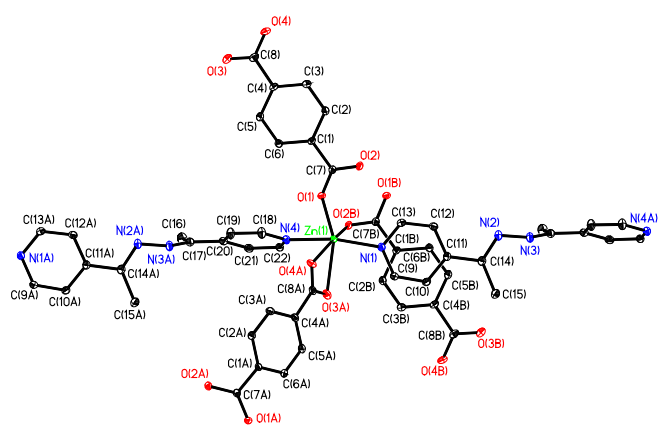

(a)

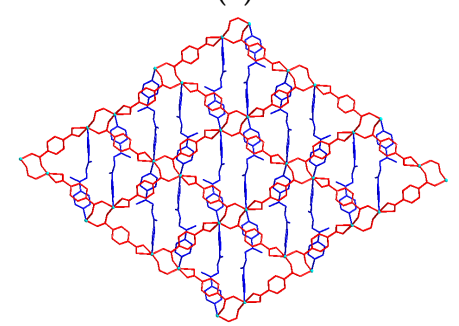

(c)

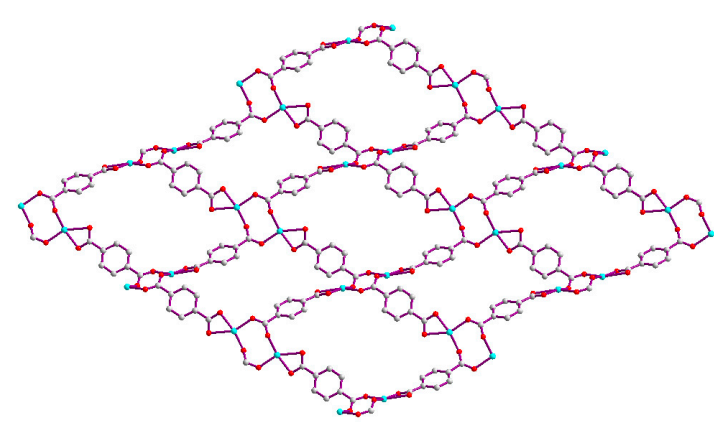

(b)

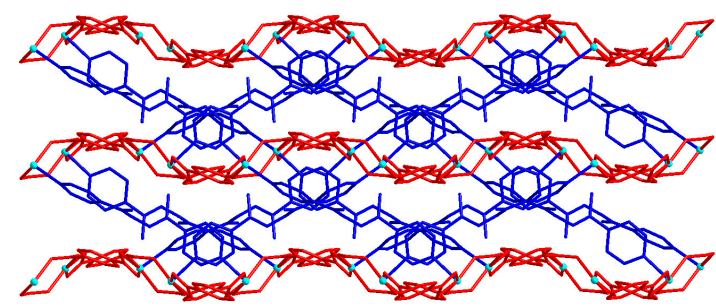

(d)

Figure 2. (a) Distorted octahedral coordination environments about $\mathrm{Zn}$ (II) ion in $\mathbf{2}$ with atom labelling scheme (ORTEP drawing, 30\% thermal ellipsoids). The $\mathrm{H}$ atoms are omitted for clarity; (b) The 2D sinusoidal-like layered framework constructed by $\mathrm{Zn}(\mathrm{II})$ and $\mathrm{bdc}^{2-}$ ligands with chelating/bidentate coordination mode viewing along the $b c$ plane; (c) The 3D MOF constructed by the 2D [Zn-bdc] layers (red) bridged by 4-bpdh ligands (blue); (d) The 3D non-interpenetrating coordination network of 2.

\subsection{Structural Description of $\left\{\left[\mathrm{Zn}_{2}(b d c)_{2}(4-b p d h)_{2}\right] \cdot(4-b p d h)\right\}_{n}(3)$}

Compound 3 crystallizes in the triclinic $P-1$ space group, in which the asymmetric unit contains two Zn(II) metal center, two bdc ${ }^{2-}$, two 4-bpdh ligands, and one free 4-bpdh guest molecule. The molecular structure of 3, as shown in Figure 3a, reveals that two crystallographically independent $\mathrm{Zn}(\mathrm{II})$ ions $(\mathrm{Zn}(1)$ and $\mathrm{Zn}(2))$ are both five coordinate bonded with three oxygen atoms of three $\mathrm{bdc}^{2-}$ ligands in the equatorial plane with $\mathrm{Zn}-\mathrm{O}$ distances in the range of 1.964(2)-2.034(2) $\AA$ and two nitrogen atoms of two 4-bpdh ligands at the axial positions with $\mathrm{Zn}-\mathrm{N}$ distances in the range 
of 2.141(3)-2.228(3) $\AA$ forming a distorted trigonal-bipyramidal (TBP) geometry. The selected bond lengths and angles around the Zn(II) centres are listed in Table S4 (deposited in the Supplementary Information). In 3, four bdc $^{2-}$ ligands adopting two different coordination modes, bis-bidentate and bis-monodentate (Scheme $2 \mathrm{a}, \mathrm{c}$ ), connect two $\mathrm{Zn}$ (II) centres generating a $\left[\mathrm{Zn}_{2}\left(\mathrm{CO}_{2}\right)_{4}\right]$ unit, and each dinuclear unit bridged by bdc $^{2-}$ ligands to form 2D planar layered frameworks (Figure 3b), with $(4,4)$ topology along the crystallographic $a b$ plane. Adjacent layers are further connected via two crystallographically independent 4-bpdh ligands, with bis-monodentate coordination mode to complete its 3D rectangular-box-like open MOF (Figure 3c). Topological analysis by TOPOS [78] suggests the presence of two types of $\mathrm{Zn}$ (II) ions that act as 6-connecting nodes, and the overall structure has a cubic (pcu $\alpha$-Po) net topology. In each dinuclear unit, two $\mathrm{Zn}$ (II) centres are separated

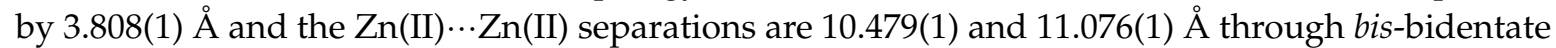
and bis-monodentate $b^{2-} c^{2-}$ bridges, respectively, and 15.605(1) $\AA$ through 4-bpdh bridge. The intra-framework spaces are then occupied by the other crystallographically identical but independent networks, which interpenetrate the first one to form a two-fold interpenetrating 3D supramolecular architecture (as shown in Figure 3d) with the vacant pores intercalated with guest 4-bpdh molecules. The effective solvent accessible void volume calculated using PLATON [79] is 16.8\% per unit cell volume after the removal of guest 4-bpdh molecules.

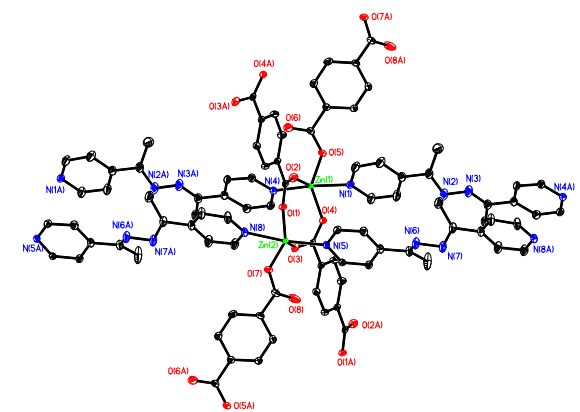

(a)

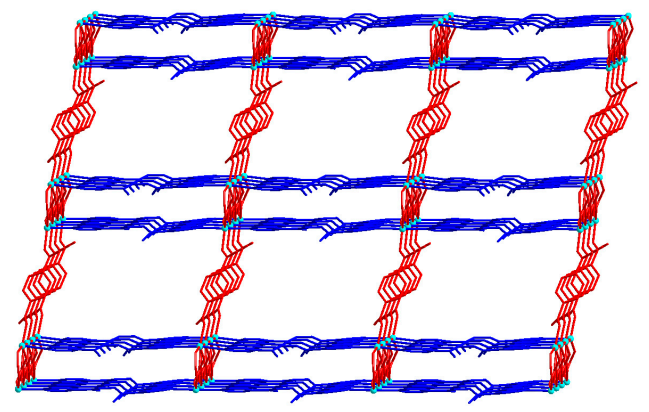

(c)

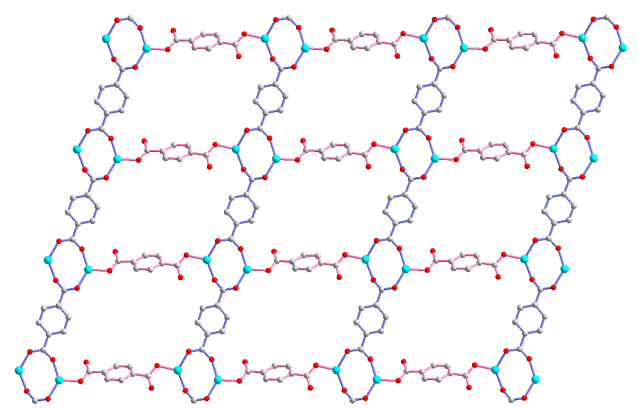

(b)

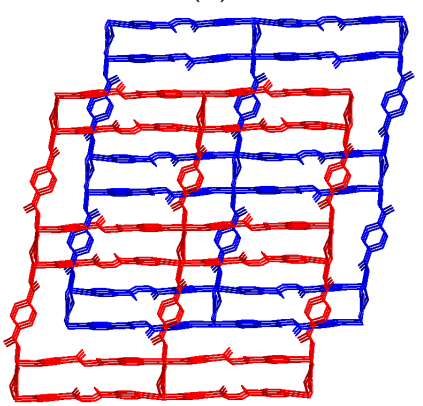

(d)

Figure 3. (a) Distorted trigonal bipyramidal coordination environments about two $\mathrm{Zn}$ (II) ions in 3 with atom labelling scheme (ORTEP drawing, 30\% thermal ellipsoids). The guest 4-bpdh molecules and $\mathrm{H}$ atoms are omitted for clarity; (b) The 2D layered framework constructed by $\mathrm{Zn}(\mathrm{II})$ and bdc ${ }^{2-}$ ligands with bis-bidentate and bis-monodentate coordination modes; (c) The 3D rectangular-box-like MOF;

(d) The two-fold interpenetrating 3D supramolecular architecture of 3.

\subsection{Structural Description of $\left\{[\mathrm{Zn}(b d c)(4-b p d h)] \cdot \mathrm{C}_{2} \mathrm{H}_{5} \mathrm{OH}\right\}_{n}(4)$}

Compound 4 crystallizes in monoclinic $C 2 / \mathrm{c}$ space group, in which the asymmetric unit contains one $\mathrm{Zn}(\mathrm{II})$ metal center located at the inversion center, one $\mathrm{bdc}^{2-}$, one 4-bpdh ligands, and one EtOH guest molecules. The molecular structure of 4, shown in Figure $4 \mathrm{a}$, reveals that the $\mathrm{Zn}(\mathrm{II})$ ion is four-coordinate bonded with two oxygen atoms of two bdc ${ }^{2-}$ with $\mathrm{Zn}-\mathrm{O}$ distance of 1.936(2) $\AA$ and two nitrogen atoms of two 4-bpdh ligands with $\mathrm{Zn}-\mathrm{N}$ distance of 2.032(2) $\AA$ forming a distorted 
tetrahedral $\left(\mathrm{T}_{d}\right)$ geometry. The selected bond lengths and angles around the $\mathrm{Zn}(\mathrm{II})$ centres are listed in Table S5 (deposited in the Supplementary Information). In 4, the $\mathrm{bdc}^{2-}$ and 4-bpdh both acts as bridging ligand with bis-monodentate (Scheme 2c) coordination modes connection the $\mathrm{Zn}(\mathrm{II})$ ions

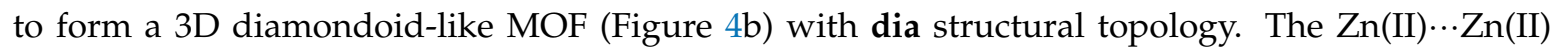
separations are 10.925(1) and 15.227(8) $\AA$ through bdc $^{2-}$ and 4-bpdh bridges, respectively. Topological analysis by TOPOS [78] suggests that each $\mathrm{Zn}$ (II) atom acts as a 4-connected node and the overall structure has a (dia) net topology. The much larger intra-framework spaces are occupied by four other crystallographically identical but independent networks, which interpenetrate the first one, as well as each other to form a five-fold interpenetrating 3D supramolecular architecture (as shown in Figure 4c), generating one-dimensional (1D) channels along the $b$ axis (Figure $4 \mathrm{~d}$ ) intercalated with ethanol molecules. The effective solvent accessible void volume calculated using PLATON [79] is $\sim 27.4 \%$ per unit cell volume after the removal of the ethanol molecules.

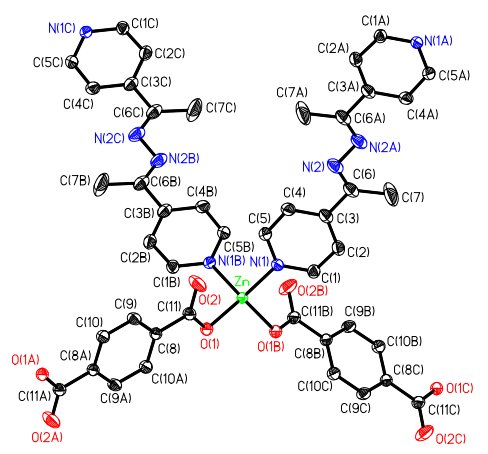

(a)

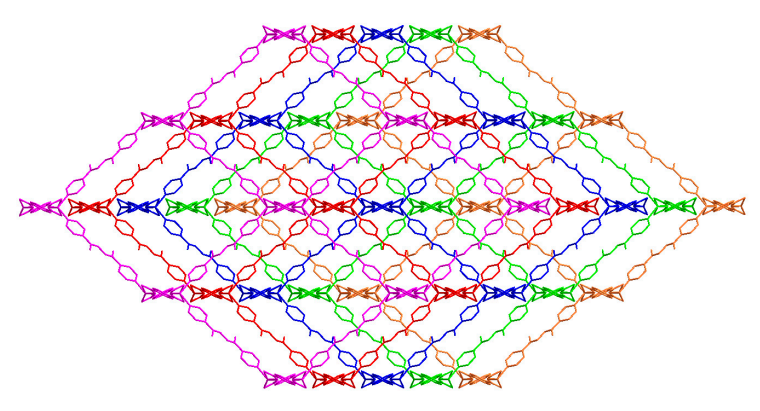

(c)

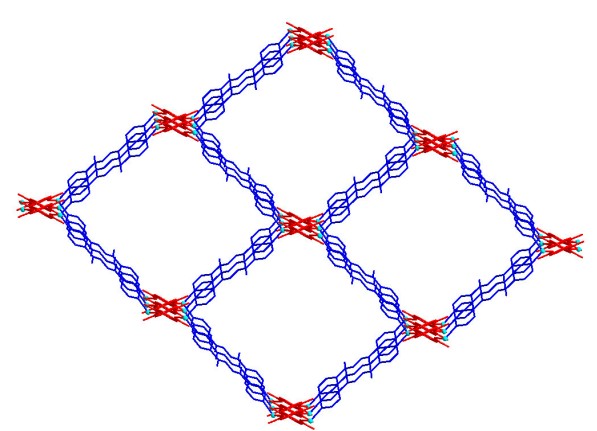

(b)

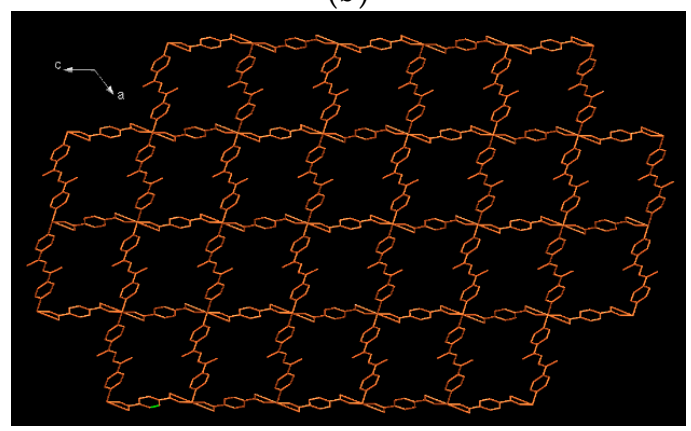

(d)

Figure 4. (a) Distorted tetrahedral coordination environments about $\mathrm{Zn}(\mathrm{II})$ ion in 4 with atom labelling scheme (ORTEP drawing, 30\% thermal ellipsoids). The solvent molecules and $\mathrm{H}$ atoms are omitted for clarity; (b) The 3D diamondoid-like MOF; (c) The five-fold interpenetrating 3D supramolecular architecture of 4 ; (d) The one-dimensional (1D) channels created by the five-fold interpenetrating 3D architecture viewing along the $b$ axis.

\subsection{Thermal Stability of CPS $\mathbf{1}-\mathbf{4}$}

To assess the thermal stability and structural variation as a function of the temperature, thermogravimetric (TG) analysis and in-situ temperature dependent XRD measurements of compounds 1-4 were performed on single-phase polycrystalline samples (Figures S1a-S4a deposited in Supplementary Information). During the heating process, the TG analysis (see Figure S1a in the Supplementary Information) revealed that compound 1 underwent a two-step weight loss and the first weight loss of $10.2 \%$ (calc. $9.4 \%$ ), corresponding to the loss of solvated ethanol and water molecules that occurred in the range of approximate $29-71{ }^{\circ} \mathrm{C}$, and then thermal stable up to $234{ }^{\circ} \mathrm{C}$ without any weight loss. On further heating, these samples decomposed at approximately $234-500{ }^{\circ} \mathrm{C}$. The TG analysis of $\mathbf{2}$ and $\mathbf{3}$ (Figures S2a and S3a in the Supplementary Information) revealed that $\mathbf{2}$ and $\mathbf{3}$ are 
thermally stable up to 310 and $217^{\circ} \mathrm{C}$, respectively, and then underwent a one-step but continuous weight loss in the temperature range of $310-500{ }^{\circ} \mathrm{C}$ for 2 and $217-480^{\circ} \mathrm{C}$ for 3 , respectively. The TG analysis of 4 (Figure S4a in the Supplementary Information) shows that the first weight loss of $7.6 \%$ (calc. 8.2\%), corresponding to the loss of ethanol molecules, occurred in the range of approximate $40-100{ }^{\circ} \mathrm{C}$, and then thermal stable up to $235^{\circ} \mathrm{C}$. On further heating, these samples decomposed at approximately $235-500^{\circ} \mathrm{C}$. All of the final products of compounds $1-4$ is probably zinc oxide $(\mathrm{ZnO})$. To gain the structural changes in depth, in situ synchrotron X-ray powder diffraction patterns of 1 were collected continuously from $25^{\circ} \mathrm{C}$ to $410{ }^{\circ} \mathrm{C}$, and the results at some specific temperatures are shown in Figure S1b (deposited in the Supplementary Information). Based on the result of TG analysis, the solvated solvent molecules in the channels of $\mathbf{1}$ are lost even at RT. The powder XRD patterns of 1 at RT, $50{ }^{\circ} \mathrm{C}$ and $80{ }^{\circ} \mathrm{C}$ reveal that they are a little different to the simulation one of 1 . This result may be due to the continuous changing in the composition of solvated solvents. However, it shows a phase transition at $90^{\circ} \mathrm{C}$, and then stable in the temperature range from $110{ }^{\circ} \mathrm{C}$ to $230{ }^{\circ} \mathrm{C}$. As the temperature rising above to $260^{\circ} \mathrm{C}$ to $350{ }^{\circ} \mathrm{C}, \mathbf{1}$ transforms to another crystalline phase and finally decomposed at above $450^{\circ} \mathrm{C}$. The powder XRD pattern (Figure S2b deposited in the Supplementary Information) of 2 at RT is almost identical to the simulation one obtained from single-crystal X-ray diffraction data. There is no phase transition below $290{ }^{\circ} \mathrm{C}$ based on the powder XRD patterns shown in Figure S2b. At about $290^{\circ} \mathrm{C}$, the phase transition occurred and further phase transition at $320^{\circ} \mathrm{C}$ was observed. As the temperature rising to above $380^{\circ} \mathrm{C}, 2$ decomposed and transformed to metal oxide. The powder XRD pattern (Figure S3b deposited in the Supplementary Information) of $\mathbf{3}$ at RT showed no obvious different to that at RT with solvents and also similar to the simulation one obtained from single-crystal X-ray diffraction data. This result indicates that the solvated solvents in 3 are relatively strong intermolecular interaction with the main framework. The powder XRD pattern at $140{ }^{\circ} \mathrm{C}$ of dry sample showed an obvious structural change of the two-fold interpenetration frameworks due to the loss of solvents. At above $200{ }^{\circ} \mathrm{C}$, the second phase transition occurred and at above $290^{\circ} \mathrm{C}$, the XRD pattern changed and gradually transform to simple metal oxide at above $320^{\circ} \mathrm{C}$. The powder XRD pattern (Figure S4b deposited in the Supplementary Information) of 4 at RT is almost identical to the simulation one that was obtained from single-crystal X-ray diffraction data. There is no phase transition below $80^{\circ} \mathrm{C}$ based on the powder XRD patterns shown in Figure S4b. At about $110{ }^{\circ} \mathrm{C}$, the phase transition occurred and further phase transition at $230{ }^{\circ} \mathrm{C}$ was observed. As the temperature rising to above $350{ }^{\circ} \mathrm{C}, 4$ decomposed and transformed to metal oxide. All of the in-situ PXRD measurements are in consistent with the TG analyses.

\subsection{Factors Affecting the Structural Diversity and Interpenetrating of CPs 1-4}

As discussed above, it is interesting to note that, under the same synthetic condition (the same starting materials of $\mathrm{Zn}(\mathrm{II})$ salt and mixed ligands, $\mathrm{bdc}^{2-}$ and 4-bpdh), the four CPs exhibit different 3D framework structure, and compounds 2, 3, and 4 can be described as supramolecular isomers [80]. The structural diversity among 1-4 are mainly attributed to the different building blocks, and the various coordination modes of $\mathrm{bdc}^{2-}$ ligands and conformations of 4-bpdh ligand, which play important roles on the construction of their 3D frameworks, and structural interpenetration. First of all, different coordination numbers and geometries of $\mathrm{Zn}$ (II) centres are undoubtedly an important factor influencing the structural topology of $\mathbf{1 - 4}$, in this study, the coordination geometry (coordination number (C. N.)) of $\mathrm{Zn}(\mathrm{II})$ centres are SP (5), distorted $\mathrm{O}_{h}(6), \mathrm{TBP}(5)$, and $\mathrm{T}_{d}$ (4) for 1, 2, 3, and 4, respectively. The second important factor is the different coordination mode of $\mathrm{bdc}^{2-}$ ligands used in CPs 1-4, including bis-bidentate coordination mode in $\mathbf{1}$, chelating/bidentate coordination mode in $\mathbf{2}$, hybrid bis-bidentate and bis-monodentate coordination modes in $\mathbf{3}$, and bis-monodentate coordination mode in 4, respectively. Different coordination geometries of $\mathrm{Zn}$ (II) centres associated with 4-bpdh and $\mathrm{bdc}^{2-}$ with different coordination modes not only generate different 3D coordination frameworks, but also create different vacant spaces for the structural interpenetration. For $\mathbf{1}$ and 3, the smaller void spaces constructed by the cube-like and rectangular-box-like 3D MOFs intercalated with guest 
molecules (EtOH and $\mathrm{H}_{2} \mathrm{O}$ for $\mathbf{1}$ and 4-bpdh for 3) results in the formation of two-fold interpenetrating supramolecular architecture. However, for 4 , the diamondoid 3D MOF with larger void space results in the formation of a five-fold interpenetrating supramolecular architecture. Many similar 3D diamondoid frameworks constructed by Schiff-base ligands (3-, 4-bpd and 3-, 4-bphd) and muli-carboxylate ligands all display highly (5-fold, 6-fold, and 7-fold) interpenetrating architectures [52-72]. In 2, the alternate cross-linkage bridging manner and the steric hindrance of two methyl groups in 4-bpdh ligands prevents the mutually interpenetration of the unique 3D MOFs, and shows a non-interpenetrating coordination network. These results described above may be concluded that the coordination numbers and geometries of metal centres, the coordination modes of $\mathrm{bdc}^{2-}$ ligand, and guest molecules all play an important key factor on the influence of the structural interpenetration.

\subsection{Gas-Sorption Studies of CPs $\mathbf{1}-\mathbf{4}$}

The thermal stability of microporous MOF associated with gases de-/ad-sorption properties may play a key role for the potential application on the gas storage. To examine the porous nature of compounds 1-4, we have performed gas adsorption studies with $\mathrm{N}_{2}, \mathrm{H}_{2}$ at $77 \mathrm{~K}$, and $\mathrm{CO}_{2}$ at $195 \mathrm{~K}$, respectively. In the cases of compounds $\mathbf{1}, \mathbf{3}$, and $\mathbf{4}$, although they contain lattice water, ethanol solvents (1 and 4), or free 4-bphd ligand (3), the pores are blocked due to the two-fold (1 and 3 ) and five-fold (4) interpenetration of the 3D networks. As a result, they show negligible or much less uptake $\mathrm{N}_{2}, \mathrm{H}_{2}$, and $\mathrm{CO}_{2}$ adsorption (Figure S5 deposited in the Supplementary Information), indicating the blockage of pores. In compound 2 , the non-interpenetrating $3 \mathrm{D}$ network is constructed by $2 \mathrm{D}[\mathrm{Zn}(\mathrm{bdc})]$ layered frameworks, bridged by 4-bphd ligands in a cross-linkage manner, which prevents the entrance of solvent molecule. As a result, it also shows negligible $\mathrm{N}_{2}, \mathrm{H}_{2}$, and $\mathrm{CO}_{2}$ adsorption, indicating the blockage of pores.

\subsection{Luminescence Property of CPs $\mathbf{1}-\mathbf{4}$}

The solid-state adsorption and emission properties of 1-4 were also investigated at room temperature. The title compounds all have strong absorption at $<350 \mathrm{~nm}$, a $325 \mathrm{~nm}$ laser line was therefore used as an excitation source throughout the measurements. As shown in Figure 5, the adsorption and emission bands of 1-4 in single crystal form are broad and structureless. Upon $325 \mathrm{~nm}$ excitation, the emission spectra with maxima centered around $550 \mathrm{~nm}$ for 1-3, and $592 \mathrm{~nm}$ for 4 were observed, respectively. From our previous study [81], we know that the free ligand $\mathrm{Na}_{2}$ bdc in single crystal form exhibits a fluorescence with a peak wavelength at $419 \mathrm{~nm}$, which is attributed to the $\pi^{*}-\mathrm{n}$ transitions. The emission band of 4-bpdh in the powder form with center around $570 \mathrm{~nm}$ and assigned it to the $\pi^{*}-\mathrm{n}$ transitions (Figure $\mathrm{S} 6$ in the Supplementary Information). Also, according the report of Nagaraja et al., the emissions from compound $\left[\mathrm{Zn}_{4}(\mathrm{muco})_{4}(4 \mathrm{bpdh})_{4}\right] .4 \mathrm{bpdh} .2 \mathrm{H}_{2} \mathrm{O}$ (where, muco $=$ trans, trans-muconate dianion) might be arising due to mixture characteristics of intraligand and ligand-to-ligand charge transitions [82]. Hence, the emissions from 1-4 might be ascribed due to characteristics of $\pi^{*}-n$ transitions, i.e., ligand-based transition, or/and ligand-to-ligand charge transfer. Also, we found that the increase in emission intensity for 1-4 in the single crystal at RT is larger than that of free ligands, i.e., $\mathrm{Na}_{2} \mathrm{bdc}$ and 4-bpdh, by more than 2-3 folds, manifesting the role of $\mathrm{Zn}$ (II), which acts as a bridge to enhance the rigidity of the framework.

Finally, according to the distinctly different single crystal structures, the difference in emission properties among 1-4 seem to be attributed to the different architectures of the associated crystal packing. We then inspected the effects of the stereochemistry of the ligand-metal complexes and the architectures of the associated crystal packing. Unlike 1 to 3 , the absorption and emission bands for 4 tend to be red-shifted relative to those of 1,2 , and 3 . Due to the different coordination geometry around the center $\mathrm{Zn}$ (II) in 1-4, the distances of $\mathrm{Zn}-\mathrm{O}$ and $\mathrm{Zn}-\mathrm{N}$ between the ligand and $\mathrm{Zn}(\mathrm{II})$ are different. The distances of $\mathrm{Zn}-\mathrm{O}$ and $\mathrm{Zn}-\mathrm{N}$ in 4 are slightly shorter than those in 1-3. As a result, compound 4 exhibits a lower energy emission compared with that for 1-3. 


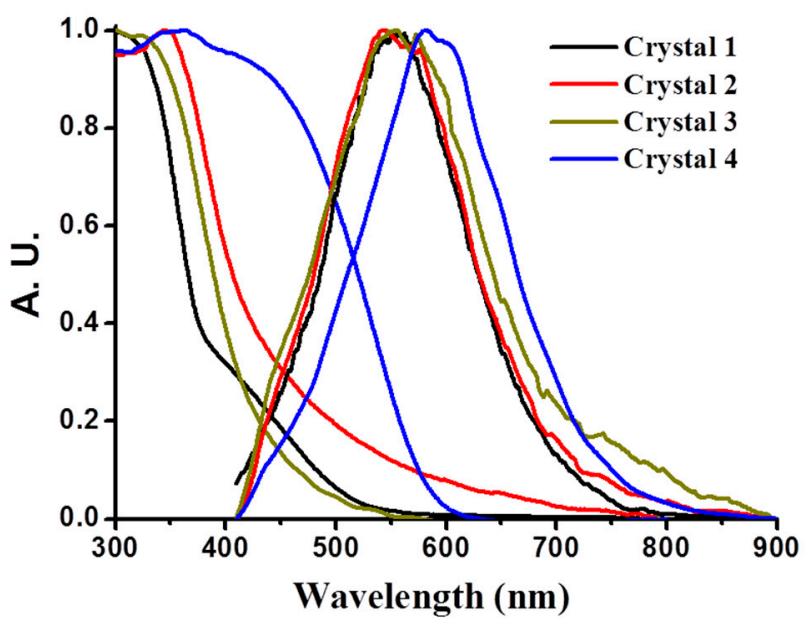

Figure 5. The UV-vis diffusive reflectance and emission spectra of 1-4 at $\lambda_{\mathrm{ex}}=325 \mathrm{~nm}$.

\section{Conclusions}

To sum up, based on a facile one-pot synthetic routes, we demonstrate the structural versatility of the $\mathrm{Zn}(\mathrm{II})$ centre bridged by $\mathrm{bdc}^{2-}$ and 4-bpdh ligands under the same synthetic conditions for building up four 3D CPs, $\left\{\left[\mathrm{Zn}_{2}(\mathrm{bdc})_{2}(4-\mathrm{bpdh})\right] \cdot \mathrm{C}_{2} \mathrm{H}_{5} \mathrm{OH} \cdot 2 \mathrm{H}_{2} \mathrm{O}\right\}_{\mathrm{n}}(\mathbf{1}),[\mathrm{Zn}(\mathrm{bdc})(4-\mathrm{bpdh})]_{\mathrm{n}}(\mathbf{2})$, $\left\{\left[\mathrm{Zn}_{2}(\mathrm{bdc})_{2}(4-\mathrm{bpdh})_{2}\right] \cdot(4-\mathrm{bpdh})\right\}_{\mathrm{n}}(3)$, and $\left\{[\mathrm{Zn}(\mathrm{bdc})(4-\mathrm{bpdh})] \cdot \mathrm{C}_{2} \mathrm{H}_{5} \mathrm{OH}\right\}_{\mathrm{n}}(4)$. All of their 3D MOFs are unique and different, including a SP Zn(II) coordination geometry with two-fold interpenetrating cube-like 3D coordination network for 1 , an $\mathrm{O}_{h}$ coordination geometry, with non-interpenetrating 3D coordination network for 2 , a TBP coordination geometry with two-fold interpenetrating rectangular-box-like 3D coordination network for 3 , and a $\mathrm{T}_{d}$ coordination geometry with five-fold interpenetrating 3D diamondoid-like coordination network for 4, respectively. The structural characteristics of CPs 1-4 provide a systematic study on the factors that affect the structural diversity of their 3D MOFs, including the coordination geometry of $\mathrm{Zn}(\mathrm{II})$ centre, the coordination modes of $\mathrm{bdc}^{2-}$, the conformational freedom of the spacer diaza moiety $(-\mathrm{CR}=\mathrm{N}-\mathrm{N}=\mathrm{CR}-)$ between the two pyridyl groups in the 4-bpdh ligands and guest molecules. A summary and comparisons of the structural characteristics among 1-4 and are listed in Table 2. These results also exemplify a unique models on the construction of the 3D MOFs, and structural interpenetration. Photoluminescence study of the compounds 1-4 were carried out at room temperature and showed emissions due to ligand-based transition ( $\pi^{*}-\mathrm{n}$ transition), or/and ligand-to-ligand charge transfer transitions.

Table 2. Summary of structural characteristics in compounds 1-4.

\begin{tabular}{ccccc}
\hline Compound & $\mathbf{1}$ & $\mathbf{2}$ & $\mathbf{3}$ & $\mathbf{4}$ \\
\hline C. N. of $\mathrm{Zn}(\mathrm{II})$ & 5 & 6 & 5 & 4 \\
Geometry of $\mathrm{Zn}(\mathrm{II})$ center & $\mathrm{SP}$ & $\mathrm{O}_{h}$ & $\mathrm{TBP}$ & $\mathrm{T}_{d}$ \\
Coordination mode of bdc ${ }^{2-}$ & bis-bidentate & chelating/bidentate & bis-bidentate \& & bis-monodentate \\
Interpenetration & Two-fold & None & Two-fold & Five-fold \\
Guest molecule & EtOH, $\mathrm{H}_{2} \mathrm{O}$ & None & 4-bpdh & EtOH \\
\hline
\end{tabular}

Supplementary Materials: The following are available online at http:/ /www.mdpi.com/2073-4360/9/12/644/s1, Figure S1: (a) Thermogravimetric (TG) measurement of 1. (b) Temperature-dependent powder X-ray diffraction patterns of 1 from room temperature to $410{ }^{\circ} \mathrm{C}$ and its simulation from single-crystal diffraction data, Figure S2: (a) Thermogravimetric (TG) measurement of 2. (b) Temperature-dependent powder X-ray diffraction patterns of 2 from room temperature to $380^{\circ} \mathrm{C}$ and its simulation from single-crystal diffraction data, Figure S3: (a) Thermogravimetric (TG) measurement of 3. (b) Temperature-dependent powder X-ray diffraction patterns of 3 from room temperature to $380{ }^{\circ} \mathrm{C}$ and its simulation from single-crystal diffraction data, Figure S4: (a) Thermogravimetric (TG) measurement of 4. (b) Temperature-dependent powder X-ray diffraction patterns of 4 
from room temperature to $380^{\circ} \mathrm{C}$ and its simulation from single-crystal diffraction data, Figure S5: (a) $\mathrm{N}_{2}$ Gas ad-/de-sorption isotherms (b) $\mathrm{H}_{2}$ Gas ad-/de-sorption isotherms (c) $\mathrm{CO}_{2}$ Gas ad-/de-sorption isotherms for 1-4, Figure S6: The UV-vis diffusive reflectance and emission spectra of 4-bpdh. $\lambda_{\mathrm{ex}}=325 \mathrm{~nm}$, Table S1: The yields of compounds 1-4 in the EtOH: $\mathrm{H}_{2} \mathrm{O}$ solution with different $\mathrm{EtOH}: \mathrm{H}_{2} \mathrm{O}$ mixing volume ratios, Table S2: Bond lengths $(\AA)$ around $\mathrm{Zn}(\mathrm{II})$ ions in 1, Table S3: Bond lengths $(\AA)$ around $\mathrm{Zn}(\mathrm{II})$ ions in 2, Table S4: Bond lengths $(\AA)$ around $\mathrm{Zn}(\mathrm{II})$ ions in 3, Table S5: Bond lengths (Å) around Zn(II) ions in 4.

Acknowledgments: The authors wish to thank the Ministry of Science and Technology, Taiwan and Soochow University for financial support.

Author Contributions: Chih-Chieh Wang conceived and designed the experiments; Szu-Yu Ke, Chia-Wen Cheng, Yu-Wen Wang and Hsiao-Shan Chiu performed the experiments, including synthesis, structural characterization, EA, IR, TG analysis and gas-absorption measurements of compounds; Mei-Lin Ho, Yu-Chien Ko, and Ning-Kuei Sun contributed to measurements of luminescence property and analyzed the data; Gene-Hsiang Lee contributed to the single-crystal X-ray Data collection and structural analysis of compounds 1-4; Chung-Kai Chang and Yu-Chun Chuang contributed to the powder X-ray diffraction measurements of compounds 1-4 by synchrotron radiation light source; Chih-Chieh Wang and Mei-Lin Ho wrote the paper.

Conflicts of Interest: The authors declare no conflict of interest.

\section{References}

1. Batten, S.R.; Champness, N.R.; Chen, X.M.; Garcia-Martinez, J.; Kitagawa, S.; Öhrström, L.; O'Keeffe, M.; Suh, M.P.; Reedijk, J. Coordination polymers, metal-organic frameworks and the need for terminology guidelines. CrystEngComm 2012, 14, 3001-3004. [CrossRef]

2. Batten, S.R.; Champness, N.R.; Chen, X.M.; Garcia-Martinez, J.; Kitagawa, S.; Öhrström, L.; O'Keeffe, M.; Suh, M.P.; Reedijk, J. Terminology of metal-organic frameworks and coordination polymers. Pure Appl. Chem. 2013, 85, 1715-1724. [CrossRef]

3. Li, B.; Chrzanowski, M.; Zhang, Y.; Ma, S. Applications of metal-organic frameworks featuring multi-functional sites. Coord. Chem. Rev. 2016, 307, 106-129. [CrossRef]

4. Zhang, X.; Wang, W.; Hu, Z.; Wang, G.; Uvdal, K. Coordination polymers for energy transfer: Preparations, properties, sensing applications, and perspectives. Coord. Chem. Rev. 2015, 284, 206-235. [CrossRef]

5. Bradshaw, D.; Claridge, J.B.; Cussen, E.J.; Prior, T.J.; Rosseinsky, M.J. Design, Chirality, and Flexibility in Nanoporous Molecule-Based Materials. Acc. Chem. Res. 2015, 38, 273-282. [CrossRef] [PubMed]

6. Silva, P.; Vilela, S.M.F.; Tome, J.P.C.; Paz, F.A.A. Multifunctional metal-organic frameworks: From academia to industrial applications. Chem. Soc. Rev. 2015, 44, 6774-6803. [CrossRef] [PubMed]

7. Li, S.; Huo, F. Metal-organic framework composites: From fundamentals to applications. Nanoscale 2015, 7, 7482-7501. [CrossRef] [PubMed]

8. Janiak, C.; Vieth, J.K. MOFs, MILs and more: Concepts, properties and applications for porous coordination networks (PCNs). New J. Chem. 2010, 34, 2366-2388. [CrossRef]

9. He, Y.; Li, B.; O'Keeffe, M.; Chen, B. Multifunctional metal-organic frameworks constructed from meta-benzenedicarboxylate units. Chem. Soc. Rev. 2014, 43, 5618-5656. [CrossRef] [PubMed]

10. Lin, Z.J.; Lu, J.; Hong, M.; Cao, R. Metal-organic frameworks based on flexible ligands (FL-MOFs): Structures and applications. Chem. Soc. Rev. 2014, 43, 5867-5895. [CrossRef] [PubMed]

11. Wang, H.; Meng, W.; Wu, J.; Ding, J.; Hou, H.; Fan, Y. Crystalline central-metal transformation in metal-organic frameworks. Coord. Chem. Rev. 2016, 307, 130-146. [CrossRef]

12. Burtch, N.C.; Walton, K.S. Modulating Adsorption and Stability Properties in Pillared Metal-Organic Frameworks: A Model System for Understanding Ligand Effects. Acc. Chem. Res. 2015, 48, 2850-2857. [CrossRef] [PubMed]

13. De Voorde, B.V.; Bueken, B.; Denayer, J.; De Vos, D. Adsorptive separation on metal-organic frameworks in the liquid phase. Chem. Soc. Rev. 2014, 43, 5766-5788. [CrossRef] [PubMed]

14. Hu, Z.; Deibert, B.J.; Li, J. Luminescent metal-organic frameworks for chemical sensing and explosive detection. Chem. Soc. Rev. 2014, 43, 5815-5840. [CrossRef] [PubMed]

15. Canivet, J.; Fateeva, A.; Guo, Y.; Coasnecd, B.; Farrusseng, D. Water adsorption in MOFs: Fundamentals and applications. Chem. Soc. Rev. 2014, 43, 5594-5617. [CrossRef] [PubMed]

16. Burtch, N.C.; Jasuja, H.; Walton, K.S. Water Stability and Adsorption in Metal-Organic Frameworks. Chem. Rev. 2014, 114, 10575-10612. [CrossRef] [PubMed] 
17. Lin, R.B.; Liu, S.Y.; Ye, J.W.; Li, X.Y.; Zhang, J.P. Photoluminescent Metal-Organic Frameworks for Gas Sensing. Adv. Sci. 2016, 3. [CrossRef] [PubMed]

18. Li, M.; Li, D.; O’Keeffe, M.; Yaghi, O.M. Topological Analysis of Metal-Organic Frameworks with Polytopic Linkers and/or Multiple Building Units and the Minimal Transitivity Principle. Chem. Rev. 2014, 114, 1343-1370. [CrossRef] [PubMed]

19. Broker, G.A.; Tiekink, E.R.T. Co-crystal formation between 2,2'-dithiodibenzoic acid and each of 4,4'-bipyridine, trans-1,2-bis(4-pyridyl) ethane and 1,2-bis(4-pyridyl)ethane. CrystEngComm 2007, 9, 1096-1109. [CrossRef]

20. Lan, Y.Q.; Jiang, H.L.; Li, S.L.; Xu, Q. Solvent-Induced Controllable Synthesis, Single-Crystal to Single-Crystal Transformation and Encapsulation of Alq3 for Modulated Luminescence in $(4,8)$-Connected Metal-Organic Frameworks. Inorg. Chem. 2012, 51, 7484-7491. [CrossRef] [PubMed]

21. Hao, X.R.; Wang, X.L.; Shao, K.Z.; Yang, G.S.; Su, Z.M.; Yuan, G. Remarkable solvent-size effects in constructing novel porous 1,3,5-benzenetricarboxylate metal-organic frameworks. CrystEngComm 2012, 14, 5596-5603. [CrossRef]

22. Guo, M.; Sun, Z.M. Solvents control over the degree of interpenetration in metal-organic frameworks and their high sensitivities for detecting nitrobenzene at ppm level. J. Mater. Chem. 2012, 22, 15939-15946. [CrossRef]

23. Karmakar, A.; Rúbio, G.M.D.M.; Guedes da Silva, M.F.C.; Hazra, S.; Pombeiro, A.J.L. Solvent-Dependent Structural Variation of Zinc(II) Coordination Polymers and Their Catalytic Activity in the Knoevenagel Condensation Reaction. Cryst. Growth Des. 2015, 15, 4185-4197. [CrossRef]

24. Roesky, H.W.; Andruh, M. The interplay of coordinative, hydrogen bonding and $\pi-\pi$ stacking interactions in sustaining supramolecular solid-state architectures: A study case of bis(4-pyridyl)- and bis(4-pyridyl-N-oxide) tectons. Coord. Chem. Rev. 2003, 236, 91-119. [CrossRef]

25. Barnett, S.A.; Champness, N.R. Structural diversity of building-blocks in coordination framework synthesis—Combining $\mathrm{M}\left(\mathrm{NO}_{3}\right)_{2}$ junctions and bipyridyl ligands. Coord. Chem. Rev. 2003, 246, 145-168. [CrossRef]

26. Pan, L.; Olson, D.H.; Ciemnolonski, L.R.; Heddy, R.; Li, J. Separation of Hydrocarbons with a Microporous Metal Organic Framework. Angew. Chem. Int. Ed. 2006, 45, 616-619. [CrossRef] [PubMed]

27. Wang, X.L.; Qin, C.; Wang, E.B.; Xu, L.; Su, Z.M.; Hu, C.W. Interlocked and Interdigitated Architectures from Self-Assembly of Long Flexible Ligands and Cadmium Salts. Angew. Chem. Int. Ed. 2004, 43, 5036-5040. [CrossRef] [PubMed]

28. Kim, H.; Chun, H.; Kim, G.H.; Lee, H.S.; Kim, K. Vapor phase inclusion of ferrocene and its derivative in a microporous metal-organic porous material and its structural characterization by single crystal X-ray diffraction. Chem. Commun. 2006, 2759-2761. [CrossRef]

29. Wu, H.; Yang, J.; Su, Z.M.; Batten, S.R.; Ma, J.F. An Exceptional 54-Fold Interpenetrated Coordination Polymer with $10^{3}$-srs Network Topology. J. Am. Chem. Soc. 2011, 133, 11406-11409. [CrossRef] [PubMed]

30. Rowsell, J.L.C.; Yaghi, O.M. Strategies for hydrogen storage in metal-organic frameworks. Angew. Chem. Int. Ed. 2005, 44, 4670-4679. [CrossRef] [PubMed]

31. Ryan, P.; Broadbelt, L.J.; Snurr, R.Q. Is catenation beneficial for hydrogen storage in metal-organic frameworks? Chem. Commun. 2008, 4132-4134. [CrossRef] [PubMed]

32. Ma, S.; Eckert, J.; Forster, P.M.; Yoon, J.W.; Hwang, Y.K.; Chang, J.S.; Collier, C.D.; Parise, J.B.; Zhou, H.C. Further Investigation of the Effect of Framework Catenation on Hydrogen Uptake in Metal-Organic Frameworks. J. Am. Chem. Soc. 2008, 130, 15896-15902. [CrossRef] [PubMed]

33. Ma, S.; Sun, D.; Ambrogio, M.; Fillinger, J.A.; Parkin, S.; Zhou, H.C. Framework-Catenation Isomerism in Metal-Organic Frameworks and Its Impact on Hydrogen Uptake. J. Am. Chem. Soc. 2007, 129, 1858-1859. [CrossRef] [PubMed]

34. Jiang, H.L.; Tatsu, Y.; Lu, Z.H.; Xu, Q. Non-, Micro-, and Mesoporous Metal-Organic Framework Isomers: Reversible Transformation, Fluorescence Sensing, and Large Molecule Separation. J. Am. Chem. Soc. 2010, 132, 5586-5587. [CrossRef] [PubMed]

35. Bureekaew, S.; Sato, H.; Matsuda, R.; Kubota, Y.; Hirose, R.; Kim, J.; Kato, K.; Takata, M.; Kitagawa, S. Control of Interpenetration for Tuning Structural Flexibility Influences Sorption Properties. Angew. Chem. Int. Ed. 2010, 49, 7660-7664. [CrossRef] [PubMed] 
36. Roberts, J.M.; Farha, O.K.; Sarjeant, A.A.; Hupp, J.T.; Scheidt, K.A. Two Azolium Rings Are Better Than One: A Strategy for Controlling Catenation and Morphology in Zn and Cu Metal-Organic Frameworks. Cryst. Growth Des. 2011, 11, 4747-4750. [CrossRef]

37. Wang, Q.; Zhang, J.; Zhuang, C.F.; Tang, Y.; Su, C.Y. Guest Inclusion and Interpenetration Tuning of $\mathrm{Cd}(\mathrm{II}) / \mathrm{Mn}(\mathrm{II})$ Coordination Grid Networks Assembled from a Rigid Linear Diimidazole Schiff Base Ligand. Inorg. Chem. 2009, 48, 287-295. [CrossRef] [PubMed]

38. Ma, L.; Lin, W. Chirality-Controlled and Solvent-Templated Catenation Isomerism in Metal-Organic Frameworks. J. Am. Chem. Soc. 2008, 130, 13834-13835. [CrossRef] [PubMed]

39. Hao, H.J.; Sun, D.; Liu, F.J.; Huang, R.B.; Zheng, L.S. Discrete Octamer Water Cluster and 1D T5(2) Water Tape Trapped in Two Luminescent Zn(II)/1,2-Bis(imidazol-1'-yl)ethane/Dicarboxylate Hosts: From 2D $(4,4)$ Net to 3D 5-Fold Interpenetrated Diamond Network. Cryst. Growth Des. 2011, 11, 5475-5482. [CrossRef]

40. Nijem, N.; Veyan, J.F.; Kong, L.; Li, K.; Pramanik, S.; Zhao, Y.; Li, J.; Langreth, D.; Chabal, Y.J. Interaction of Molecular Hydrogen with Microporous Metal Organic Framework Materials at Room Temperature. J. Am. Chem. Soc. 2010, 132, 1654-1664. [CrossRef] [PubMed]

41. Curtin, D.M.; Dong, Y.B.; Smith, M.D.; Barclay, T.; zur Loye, H.C. Two Versatile N,N'-Bipyridine-Type Ligands for Preparing Organic-Inorganic Coordination Polymers: New Cobalt- and Nickel-Containing Framework Materials. Inorg. Chem. 2001, 40, 2825-2834. [CrossRef]

42. Shi, Y.J.; Li, L.H.; Xu, Y.; Chen, X.T.; Xue, Z.; You, X.Z. Syntheses and structures of two- and one-dimensional organic-inorganic hybrid compounds assembled from $\mathrm{PbI}_{2}$ and 1,4-bis(4-pyridyl)-2,3-diaza-1,3-butadiene. Inorg. Chem. Commun. 2002, 5, 1090-1094. [CrossRef]

43. Shen, L. Synthesis, crystal structure and magnetic property of a novel sheet-like polymer $\left[\mathrm{Mn}(\mathrm{bpd})(\mathrm{NCS})_{2}\left(\mathrm{CH}_{3} \mathrm{OH}\right)_{2}\right]_{n}$ (bpd = 1,4-bis(4-pyridyl)-2,3-diaza-1,3-butadiene). Inorg. Chem. Commun. 2003, 6, 1133-1136. [CrossRef]

44. Patra, G.K.; Goldberg, I. Supramolecular Design of Coordination Complexes of Silver(I) with Polyimine Ligands: Synthesis, Materials Characterization, and Structure of New Polymeric and Oligomeric Materials. Cryst. Growth. Des. 2003, 3, 321-329. [CrossRef]

45. Dong, Y.B.; Zhao, X.; Huang, R.Q.; Smith, M.D.; zur Loye, H.C. New Ag(I)-Containing Coordination Polymers Generated from Multidentate Schiff-Base Ligands. Inorg. Chem. 2004, 43, 5603-5612. [CrossRef] [PubMed]

46. Zhao, Q.H.; Liu, Y.Q.; Fang, R.B. Synthesis, crystal structures and magnetic properties of a coordination polymer containing the $\left[\mathrm{Mn}_{5}\left(\mu_{1,1}-\mathrm{N}_{3}\right)_{8}\left(\mathrm{~N}_{3}\right)_{2}(\mathrm{bpd})_{5}\left(\mathrm{H}_{2} \mathrm{O}\right)_{2}\right]$ repeat cluster units (bpd = 1,4-bis(4-pyridyl)-2,3-diaza-1,3-butadiene). Inorg. Chem. Commun. 2006, 9, 699-702. [CrossRef]

47. Zhang, G.; Yang, G.; Ma, J.S. Anion Control of the Self-Assembly of One-Dimensional Molecular Ladders vs. Three-Dimensional Cross-like Arrays Based on a Bidentate Schiff Base Ligand. Cryst. Growth Des. 2006, 6, 1897-1902. [CrossRef]

48. Granifo, J.; Garland, M.T.; Baggio, R. The effect in the assembly and node nuclearity of the long and rigid character of bis-pyridyl exo-bidentate spacers when react with zinc acetate: Crystal structures of the high nuclearity coordination polymers $\left[\mathrm{Zn}_{7}\left(\mu_{4}-\mathrm{O}\right)_{2}(\mathrm{OAc})_{10}(3 \mathrm{pdb})\right]_{n}(3 \mathrm{pdb}=1,4$-bis(3-pyridyl)-2, 3-diaza-1,3-butadiene) and $\left[\mathrm{Zn}_{7}\left(\mu_{4}-\mathrm{O}\right)_{2}(\mathrm{OAc})_{10}(4 \mathrm{pdb})\right]_{n}(4 \mathrm{pdb}=1,4$-bis(4-pyridyl)-2,3-diaza-1,3-butadiene). Polyhedron 2006, 25, 2277-2283.

49. Wang, C.C.; Lin, W.Z.; Huang, W.T.; Ko, M.J.; Lee, G.H.; Ho, M.L.; Lin, C.W.; Shih, C.W.; Chou, P.T. New supramolecular isomers with 2D $4^{4}$ square-grid and 3D $6^{5} \cdot 8$ frameworks in a one-pot synthesis; reversible solvent uptake and intriguing luminescence properties. Chem. Commun. 2008, 1299-1301. [CrossRef] [PubMed]

50. Liu, C.Y.; Lee, G.H.; Wang, H.T. Synthesis, Structural Characterization and Thermal Stability of $\left[\mathrm{Mn}(3-\mathrm{bpd})_{2}(\mathrm{NCS})_{2}\left(\mathrm{H}_{2} \mathrm{O}\right)_{2}\right] \cdot 2 \mathrm{H}_{2} \mathrm{O}(1)$ and $\left\{\left[\mathrm{Mn}(\mathrm{bpe})(\mathrm{NCS})_{2}\left(\mathrm{H}_{2} \mathrm{O}\right)_{2}\right] \cdot(3-\mathrm{bpd}) \cdot(\mathrm{bpe}) \cdot \mathrm{H}_{2} \mathrm{O}\right\}_{n}$ (2) from One-Pot Crystallization. J. Chin. Chem. Soc. 2009, 56, 709-717. [CrossRef]

51. Liu, C.Y.; Wang, H.T.; Chung, W.C.; Cheng, Y.T.; Chen, Y.T.; Ho, M.L.; Wang, C.C.; Lee, G.H.; Sheu, H.S. Assembly of Three 2D Metal-Organic Frameworks (MOFs) Derived from Flexible Ligands, 1,4-bis(3-pyridyl)-2,3-diaza-1,3-butadiene (3-bpd) and/or 1,2-bis(4-pyridyl)ethane (dpe). J. Chin. Chem. Soc. 2012, 59, 1070-1079. [CrossRef] 
52. Dong, Y.B.; Smith, M.D.; Layland, R.C.; zur Loye, H.C. A Novel Noninterpenetrating Polycyclohexane Network: A New Inorganic/Organic Coordination Polymer Structural Motif Generated by Self-Assembly of “T-Shaped" Moieties. Chem. Mater. 2000, 12, 1156-1161. [CrossRef]

53. Dong, Y.B.; Smith, M.D.; zur Loye, H.C. New Inorganic/Organic Coordination Polymers Generated from Bidentate Schiff-Base Ligands. Inorg. Chem. 2000, 39, 4927-4935. [CrossRef] [PubMed]

54. Dong, Y.B.; Smith, M.D.; zur Loye, H.C. New Inorganic-Organic Coordination Polymers Generated from Rigid or Flexible Bidentate Ligands and $\mathrm{Co}(\mathrm{NCS})_{2} \cdot x \mathrm{H}_{2} \mathrm{O}$. J. Solid State Chem. 2000, 155, 143-153. [CrossRef]

55. Parshamoni, S.; Konar, S. Selective $\mathrm{CO}_{2}$ adsorption in four Zinc(II)-based metal organic frameworks constructed using a rigid $N, N^{\prime}$-donor linker and various dicarboxylate ligands. CrystEngComm 2016, 18, 4395-4404. [CrossRef]

56. Parshamoni, S.; Sanda, S.; Jena, H.S.; Konar, S. Tuning $\mathrm{CO}_{2}$ Uptake and Reversible Iodine Adsorption in Two Isoreticular MOFs through Ligand Functionalization. Chem. Asian J. 2015, 10, 653-660. [CrossRef] [PubMed]

57. Tahmasebi, E.; Masoomi, M.Y.; Yamini, Y.; Morsali, A. Application of Mechanosynthesized Azine-Decorated Zinc(II) Metal-Organic Frameworks for Highly Efficient Removal and Extraction of Some Heavy-Metal Ions from Aqueous Samples: A Comparative Study. Inorg. Chem. 2015, 54, 425-433. [CrossRef] [PubMed]

58. Bhattacharya, B.; Maity, D.K.; Mondal, R.; Colacio, E.; Ghoshal, D. Two Series of Isostructural Coordination Polymers with Isomeric Benzenedicarboxylates and Different Azine Based $N, N^{\prime}$-Donor Ligands: Syntheses, Characterization and Magnetic Properties. Cryst. Growth Des. 2015, 15, 4427-4437. [CrossRef]

59. Manna, B.; Singh, S.; Karmakar, A.; Desai, A.V.; Ghosh, S.K. Selective Anion Exchange and Tunable Luminescent Behaviors of Metal-Organic Framework Based Supramolecular Isomers. Inorg. Chem. 2015, 54, 110-116. [CrossRef] [PubMed]

60. Bhattacharya, B.; Haldar, R.; Maity, D.K.; Maji, T.K.; Ghoshal, D. Pillared-bilayer porous coordination polymers of $\mathrm{Zn}(\mathrm{II})$ : Enhanced hydrophobicity of pore surface by changing the pillar functionality. CrystEngComm 2015, 17, 3478-3486. [CrossRef]

61. Safarifard, V.; Beheshti, S.; Morsali, A. An interpenetrating amine-functionalized metal-organic framework as an efficient and reusable catalyst for the selective synthesis of tetrahydro-chromenes. CrystEngComm 2015, 17, 1680-1685. [CrossRef]

62. Maity, D.K.; Bhattacharya, B.; Mondal, R.; Ghoshal, D. Five diverse bivalent metal coordination polymers based on benzene dicarboxylate and bent dipyridyl ligands: Syntheses, structures, and photoluminescent properties. CrystEngComm 2014, 16, 8896-8909. [CrossRef]

63. Bhattacharya, B.; Haldar, R.; Dey, R.; Maji, T.K.; Ghoshal, D. Porous coordination polymers based on functionalized Schiff base linkers: Enhanced $\mathrm{CO}_{2}$ uptake by pore surface modification. Dalton Trans. 2014, 43, 2272-2282. [CrossRef] [PubMed]

64. Dey, R.; Bhattacharya, B.; Pachfule, P.; Banerjee, R.; Ghoshal, D. Flexible dicarboxylate based pillar-layer metal organic frameworks: Differences in structure and porosity by tuning the pyridyl based $N, N^{\prime}$ linkers. CrystEngComm 2014, 16, 2305-2316. [CrossRef]

65. Masoomi, M.Y.; Stylianou, K.C.; Morsali, A.; Retailleau, P.; Maspoch, D. Selective $\mathrm{CO}_{2} \mathrm{Capture}$ in Metal-Organic Frameworks with Azine-Functionalized Pores Generated by Mechanosynthesis. Cryst. Growth Des. 2014, 14, 2092-2096. [CrossRef]

66. Parshamoni, S.; Sanda, S.; Jena, H.S.; Tomar, K.; Konar, S. Exploration of Structural Topologies in Metal-Organic Frameworks Based on 3-(4-Carboxyphenyl)propionic Acid, Their Synthesis, Sorption, and Luminescent Property Studies. Cryst. Growth Des. 2014, 14, 2022-2033. [CrossRef]

67. Zhou, J.; Du, L.; Qiao, Y.F.; Hu, Y.; Li, B.; Li, L.; Wang, X.Y.; Yang, J.; Xie, M.J.; Zhao, Q.H. Intriguing Architectures Generated from 1,4-Bis(3- or 4-pyridyl)-2,3-diaza-1,3-butadiene with Aromatic Dicarboxylates: Syntheses, Crystal Structures, and Properties. Cryst. Growth Des. 2014, 14, 1175-1183. [CrossRef]

68. Bhattacharya, B.; Maity, D.K.; Pachfule, P.; Colacio, E.; Ghoshal, D. Syntheses, X-ray structures, catalytic activity and magnetic properties of two new coordination polymers of $\mathrm{Co}(\mathrm{II})$ and $\mathrm{Ni}$ (II) based on benzenedicarboxylate and linear $N, N^{\prime}$-donor Schiff base linkers. Inorg. Chem. Front. 2014, 1, 414-425. [CrossRef]

69. Bhattacharya, B.; Dey, R.; Maity, D.K.; Ghoshal, D. Formation of three new metal organic hybrids of Cd(II) with $N, N^{\prime}$ donor spacer: An in situ perchlorate to chloride transformation. CrystEngComm 2013, 15, 9457-9464. [CrossRef] 
70. Sanda, S.; Parshamoni, S.; Adhikary, A.; Konar, S. A Family of Metal-Organic Frameworks Based on Carboxylates and a Neutral, Long, and Rigid Ligand: Their Structural Revelation, Magnetic, and Luminescent Property Study. Cryst. Growth Des. 2013, 13, 5442-5449. [CrossRef]

71. Bhattacharya, B.; Dey, R.; Pachfule, P.; Banerjee, R.; Ghoshal, D. Four 3D Cd(II)-Based Metal Organic Hybrids with Different $N, N^{\prime}$-Donor Spacers: Syntheses, Characterizations, and Selective Gas Adsorption Properties. Cryst. Growth Des. 2013, 13, 731-739. [CrossRef]

72. Zhang, S.-Q.; Jiang, F.-L.; Wu, M.-Y.; Ma, J.; Bu, Y.; Hong, M.-C. Assembly of Discrete One-, Two-, and Three-Dimensional Zn(II) Complexes Containing Semirigid V-Shaped Tricarboxylate Ligands. Cryst. Growth Des. 2012, 12, 1452-1463. [CrossRef]

73. Siemens Analytical Instruments Division. SMART V 4.043 Software for CCD Detector System; Siemens Analytical Instruments Division: Madison, WI, USA, 1995.

74. Siemens Analytical Instruments Division. SAINT V 4.035 Software for CCD Detector System; Siemens Analytical Instruments Division: Madison, WI, USA, 1995.

75. Sheldrick, G.M. Program for the Refinement of Crystal Structures; University of Göttingen: Göttingen, Germany, 1993.

76. Siemens Analytical Instruments Division. SHELXTL 5.03 (PC-Version), Program Liberary for Structure Solution and Molecular Graphics; Siemens Analytical Instruments Division: Madison, WI, USA, 1995.

77. Toby, B.H.; Von Dreele, R.B. GSAS-II: The genesis of a modern open-source all purpose crystallography software package. J. Appl. Crystallogr. 2013, 46, 544-549. [CrossRef]

78. O'Keeffe, M.; Peskov, M.A.; Ramsden, S.J.; Yaghi, O.M. The Reticular Chemistry Structure Resource (RCSR) Database of, and Symbols for, Crystal Nets. Acc. Chem. Res. 2008, 41, 1782-1789. [CrossRef] [PubMed]

79. Spek, A.L. Single-crystal structure validation with the program PLATON. J. Appl. Crystallogr. 2003, 36, 7-13. [CrossRef]

80. Zhang, J.P.; Huang, X.C.; Chen, X.M. Supramolecular isomerism in coordination polymers. Chem. Soc. Rev. 2009, 38, 2385-2396. [CrossRef] [PubMed]

81. Wang, C.C.; Sheu, G.B.; Ke, S.Y.; Shih, C.Y.; Cheng, Y.J.; Chen, Y.T.; Cho, C.H.; Ho, M.L.; Chen, W.T.; Liao, R.H.; et al. A 3D porous supramolecular architecture via $\pi-\pi$ assembly of 2D metal-organic frameworks (MOFs): Structure-versus-luminescence reversibility and gas adsorption properties. CrystEngComm 2015, 17, 1264-1272. [CrossRef]

82. Nagaraja, C.M.; Ugale, B.; Chanthapally, A. Construction of a 2D Interwoven and 3D Interpenetrated Metal-Organic Frameworks of Zn(II) by Varying N,N'-Donor Spacers. CrystEngComm 2014, 16, 4805-4815. [CrossRef]

(C) 2017 by the authors. Licensee MDPI, Basel, Switzerland. This article is an open access article distributed under the terms and conditions of the Creative Commons Attribution (CC BY) license (http://creativecommons.org/licenses/by/4.0/). 